\title{
Immunological Perspective for Ebola Virus Infection and Various Treatment Measures Taken to Fight the Disease
}

\author{
Sahil Jain ${ }^{1}$, Svetlana F. Khaiboullina ${ }^{2,3, *}$ and Manoj Baranwal ${ }^{1, * \text { (D) }}$ \\ 1 Department of Biotechnology, Thapar Institute of Engineering \& Technology, Patiala 147004, Punjab, India; \\ drsahiljain88@gmail.com \\ 2 Department of Microbiology and Immunology, University of Nevada, Reno, NV 89557, USA \\ 3 Institute of Fundamental Medicine and Biology, Kazan Federal University, 420008 Kazan, Tatarstan, Russia \\ * Correspondence: sv.khaiboullina@gmail.com (S.F.K.); manoj.baranwal@thapar.edu (M.B.)
}

Received: 20 September 2020; Accepted: 16 October 2020; Published: 17 October 2020

\begin{abstract}
Ebolaviruses, discovered in 1976, belongs to the Filoviridae family, which also includes Marburg and Lloviu viruses. They are negative-stranded RNA viruses with six known species identified to date. Ebola virus (EBOV) is a member of Zaire ebolavirus species and can cause the Ebola virus disease (EVD), an emerging zoonotic disease that results in homeostatic imbalance and multi-organ failure. There are three EBOV outbreaks documented in the last six years resulting in significant morbidity ( $>32,000$ cases) and mortality ( $>13,500$ deaths). The potential factors contributing to the high infectivity of this virus include multiple entry mechanisms, susceptibility of the host cells, employment of multiple immune evasion mechanisms and rapid person-to-person transmission. EBOV infection leads to cytokine storm, disseminated intravascular coagulation, host T cell apoptosis as well as cell mediated and humoral immune response. In this review, a concise recap of cell types targeted by EBOV and EVD symptoms followed by detailed run-through of host innate and adaptive immune responses, virus-driven regulation and their combined effects contributing to the disease pathogenesis has been presented. At last, the vaccine and drug development initiatives as well as challenges related to the management of infection have been discussed.
\end{abstract}

Keywords: T-cell immunity; bystander apoptosis; cytokines response; host immune evasion; Ebola vaccines

\section{Introduction}

The Filoviridae family includes enveloped, non-segmented, negative-strand RNA ebolaviruses belonging to the genus Ebolavirus [1]. Until recently, six Ebolavirus species have been identified out of which, members of four species are known to be human pathogens [2]. These viruses are Ebola virus (EBOV), Sudan virus (SUDV), Taï Forest virus (TAFV) and Bundibugyo virus (BDBV) belonging to Zaire ebolavirus, Sudan ebolavirus, Tä̈ Forest ebolavirus (earlier known as Ivory coast ebolavirus or Côte d'Ivoire ebolavirus) and Bundibugyo ebolavirus species, respectively [3]. EBOV is the most pathogenic and responsible for "The Great Outbreak of West Africa" in 2014-2016, the largest known ebolavirus outbreak [2,4]. Reston virus (RESTV) and Bombali virus (BOMV), members of Reston ebolavirus and Bombali ebolavirus species respectively, are not reported to infect humans [5-7].

Ebola virus disease (EVD), earlier known as Ebola hemorrhagic fever (EHF), is a fatal illness that has been described in humans as well as primates such as monkeys, chimpanzees and gorillas (reviewed in [8]). EVD is zoonotic wherein humans become infected when contacting infected animals or handling bushmeat [9]. Human-to-human transmission was reported as well via contact with blood and body fluids from infected individuals [10]. The disease severity as well as devastating social and economic effects led to EBOV classification as a Category A Priority pathogen by National Institute 
of Allergy and Infectious Diseases (NIAID), and as a "select agent" by US federal regulations and a bioterrorism Category A Agent by the Centers for Disease Control and Prevention (CDC) [11-13].

EBOV infection leads to lymphopenia, neutrophilia, increased serum proinflammatory cytokines, disseminated intravascular coagulation (DIC), liver necrosis and lymphoid tissue necrosis (reviewed in $[8,14]$ ). Additionally, innate and adaptive (humoral and cellular) immune responses were shown to be activated during the infection (reviewed in [15]). The infection results in the activation of type-I effector mechanisms (cytotoxicity and interferon production) as well as strong $\mathrm{T}$ cell activation and differentiation (reviewed in [16]). Similar results were obtained using non-human primates (NHP) model, the 'gold-standard' animal model of EBOV infection, (reviewed in $[17,18]$ ) confirming the role of the immune response in pathogenesis of the disease.

Management of EBOV infection remains a great challenge, where lack of a specific treatment is the main cause of high mortality. Therefore, vaccines remain the best approach to control the outbreaks and prevent death. Following 2014 West African epidemic, Russia and China had regionally licensed two Ebola vaccines [19] to counter the possible regional outbreaks. However, the efficacy of these vaccines was under debate as sufficient phase III trial data is not available [20]. During the 2018 outbreak in Democratic Republic of Congo (DRC), the Ervebo vaccine (Ebola Zaire Vaccine, Live), which is based on recombinant vesicular stomatitis virus (rVSV) vector, was recommended for compassionate and investigational use in the areas with the highest risk of EVD [21]. This vaccine conferred immunogenicity against EBOV during the 2014 epidemic, prompting the European Medicine Agency (EMA) to pass a 'conditional marketing authorization' for the Ervebo vaccine on 18th October, 2019 [21]. Ervebo was approved by the Food and Drug Administration (FDA) on 19th December, 2019 as the first licensed vaccine against EBOV [22]. Currently, despite the encouraging news on the vaccine approval, there is a long way to complete, global protection against future EBOV outbreaks.

\section{Ebola Virus Disease (EVD)}

\subsection{Cell Targets}

EBOV can infect almost any cell, except lymphocytes (reviewed in [23]); however, virus propagation was demonstrated in limited cell types such as fibroblasts, endothelial cells, NK cells, epithelial cells and hepatocytes (reviewed in [24]). Within these cell range, it appears that mononuclear phagocytes (macrophages including alveolar cells, monocytes and dendritic cells) are the most susceptible to infection in the initial phase of disease [25-27]. Dendritic cells (DC) expressing DC-specific intercellular adhesion molecule (ICAM)-3-grabbing nonintegrin (DC-SIGN) were shown to be susceptible to infection as well, whereas langerin expressing cells (CD141 ${ }^{+}$DC of mucosal epithelium and skin Langerhans cells), epidermal DCs and mucosal epithelium DCs were found to be resistant (reviewed in [28]). Mononuclear phagocytes moving out of lymph nodes and spleen are thought to be responsible for viral dissemination [26].

\subsection{EBOV Attachment and Entry}

Three uptake mechanisms were identified by which EBOV could enter the cell: macro-pinocytosis, lipid raft and receptor-mediated endocytosis [23]. Reports suggest that class I phosphastidylinositol-3-kinase Akt pathway [29] and cholesterol enriched lipid raft microdomains [30] are essential for viral trafficking across the cell membrane. Additionally, multiple receptors were identified as contributing to virus attachment including glycosaminoglycans, folate receptor $\alpha, \beta 1$ integrin receptor, human macrophage galactose-and $\mathrm{N}$-acetylgalactosamine-specific $\mathrm{C}$ type lectin (hMGL), DC-SIGN, triggering receptor expressed in myeloid cells 1 (TREM-1) and various other C-type lectins [18,31-35]. EBOV is also known to interact with T-cell immunoglobin mucin domain (TIM) and Tyro3/Axl/Mer (TAM) receptors [17]. None of these receptors has been identified as critical for viral attachment.

Endocytosis precedes the uncoating and fusion between viral and endosomal membranes (reviewed in [36]). Internalization of the virus into a macropinosome is followed by its transfer to 
an endosomal compartment containing the cysteine proteases such as cathepsin B and cathepsin $\mathrm{L}$ [37]. The latter helps to digest the viral glycoprotein (GP) which initiates viral and endosomal membrane fusion [37]. Processed GP1 interacts with Neimann-Pick C1 (NPC1) protein of the late endosome (an extremely crucial interaction for EVD) which results in coupling of the virus envelope and membrane of the endosome [38]. The fusion loop domain of GP2 helps to initiate the membrane fusion by inserting into the host endosomal membranes [39]. GTPases, especially Rab7 GTPase (related to the late endosomes), play a crucial role in viral fusion [40]. A low $\mathrm{pH}$ dependent endosomal function is required by cathepsin digested GP1 subunit for fusion [41]. Therefore, fusion process can be blocked by the cysteine protease determents and increasing the $\mathrm{pH}$ of the environment [41]. After fusion, trimeric heptad regions of the GP2 subunit form a hexa-helical transmembrane structure, facilitating the release of viral proteins into the host cytoplasm where they initiate the replication process [42].

\subsection{EVD Symptoms}

EVD symptoms appear after an incubation period ranging from 2-21 days [14]. They include fever, weakness, vomiting, anorexia, abdominal pains, chills, "ghost-like" expressionless face, proteinuria and diarrhea (reviewed in [12,43]). Infection results in viremia which presents with hemorrhages (petechiae, mucosal hemorrhage, ecchymosis and visceral hemorrhage), tachycardia, electrolyte disorders, multiple vital organ (liver, respiratory and renal) failure and necrosis (reviewed in $[23,44,45]$ ). Multi-organ failure is the primary cause for death in EVD [23] while electrolyte imbalances such as hypocalcemia, hyponatremia and hypomagnesemia may lead to cardiac arrhythmias or coma [28,46,47].

Surprisingly, hemorrhage has been recorded in only $20 \%$ cases since the first outbreak and may be, partially, due to the hepatocellular necrosis, which impairs production of functional blood coagulation enzymes in liver $[28,48,49]$. Additionally, genetic and nutritional factors were suggested to contribute to hemorrhagic syndrome [28]. Interestingly, Mc Elroy et al., reported lack of correlation between hemorrhage and fatality [50]. In addition to hemorrhages, virus was shown to cause primary pulmonary infection [51], neurological complications such as seizures and tremors [52], ocular disorders such as conjunctivitis and uveitis [53] and affect the liver function [54]. Rheumatological manifestations such as arthritis, arthralgia, tendinitis, bursitis and myalgia are common in patients [55]. It appears that virus could persist in the immune privileged organs long after the clearance $[17,56]$. This assumption was supported by the detection of viral RNA in the urine, sweat and other body parts indicating the viral persistence long after the clinical symptoms subside [56].

\section{Host Immune Response}

A comprehensive diagram of the EBOV effects on the host immune response is presented in Figure 1. 


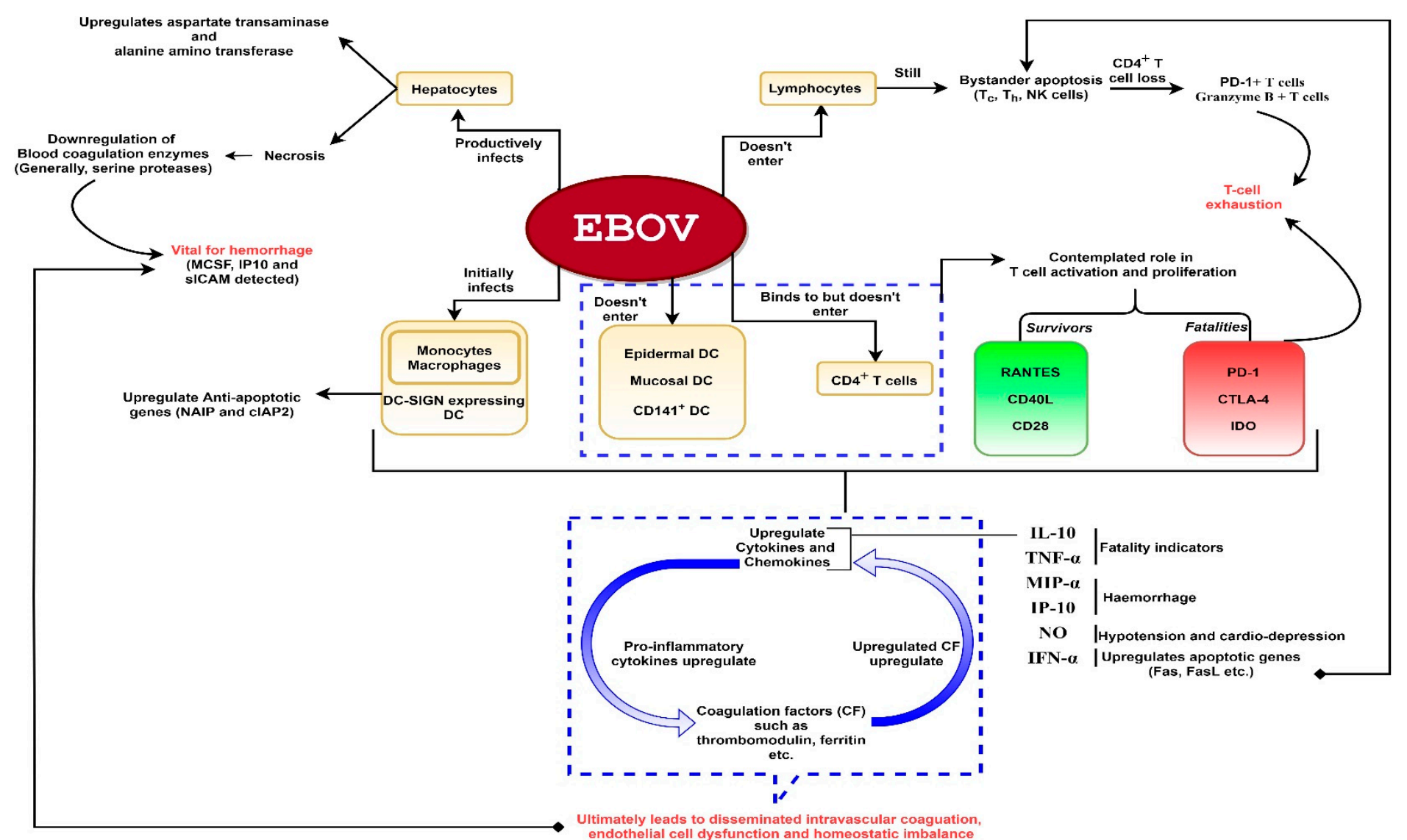

Figure 1. A schematic representation of Ebola virus (EBOV) pathogenesis. The virus is capable of productively infecting monocytes, macrophages, dendritic cells (DC) (except epidermal, mucosal and CD141 ${ }^{+}$DC) and hepatocytes. The virus does not enter lymphocytes but can show interaction with CD4 ${ }^{+} \mathrm{T}$-cells. Despite non-entry into lymphocytes, bystander lymphocyte apoptosis is observed during the course of infection which could lead to T-cell exhaustion. Infection of hepatocytes could result in downregulation of blood coagulation enzymes which could lead to hemorrhage. Severe infection leads to hyperproduction of proinflammatory cytokines. These cytokines activate coagulation factors such as thrombomodulin, ferritin etc. The released coagulation factors in turn upregulate proinflammatory cytokines, as depicted. Hence, a deadly chain reaction ensues upon filoviral infection which might culminate into shock, vascular damage (disseminated intravascular coagulation which might lead to hemorrhage especially rashes, gastrointestinal and conjunctival hemorrhage in the later stages) and homeostatic imbalance. 


\subsection{Mononuclear Phagocytes}

EBOV can affect the mononuclear phagocytes differentiation, which could interfere with their ability to recognize and present the antigen [26]. Additionally, EBOV infection of mononuclear phagocytes causes the upregulation of anti-apoptotic genes such as neuronal apoptosis inhibitory protein (NAIP) and cellular inhibitor of apoptosis protein 2 (cIAP2) [26]. Additionally, EBOV infection inhibits DC maturation which could affect the activation of an innate and adaptive immunity [18]. Interestingly, an in vitro analysis of monocyte-derived DC revealed that these cells can survive for days after infection [57], while supporting virus replication. Therefore, it was suggested that DC could serve as a vehicle disseminating the virus.

\subsection{Cell Mediated Immune Response}

\subsubsection{T-Cell Response}

Multiparametric flow cytometry analysis has revealed a robust activation of $\mathrm{T}_{\mathrm{c}}$ cells followed by a substantial proliferation in fatal as well as survivor cases $[28,56,58]$. An average of $45 \% \mathrm{CD}^{+} \mathrm{T}$ cells, consisting of $\mathrm{HLA}-\mathrm{DR}^{+} / \mathrm{CD} 38^{+}, \mathrm{Ki}-67^{+} /$granzyme $\mathrm{B}^{+}$and $\mathrm{Ki}-67^{+} / \mathrm{PD}-1^{+}$subsets, were found to express activation markers HLA-DR, Ki-67 and CD38 [56]. NHP studies focused on EBOV GP presented contrasting results regarding the indispensability of $\mathrm{CD}^{+} \mathrm{T}$ cells for EBOV infection survival $[59,60]$. In 2018, Sakabe and coworkers demonstrated that memory CD8 T cells secrete interferon gamma (IFN- $\gamma$ ) and tumor necrosis factor alpha (TNF- $\alpha$ ) in nearly $80 \%$ survivor subjects, especially upon activation with proteins other than GP viz., EBOV nucleoprotein, virion protein 24 (VP24) or VP40 [61]. Analysis of samples collected during the West African epidemic (2014-2016) by Speranza and co-workers revealed the abundance of T-cell immunity transcripts (RANTES, CD40L, CD28 etc.) in survivors and of T cell homeostasis drivers (PD-1 and Indoleamine 2,3-dioxygenase) in fatal cases, thus, confirming the notion of a robust and sustained T-cell response mounted in survivors [62]. Moreover, survivors show a characteristic chemokine (C-C motif) ligand 5 (CCL5/RANTES) expression, further, supporting the role of $\mathrm{T}$ cells in viral clearance. In contrast, the fatal cases are devoid of $\mathrm{T}$ cell viral clearance and present a clustering of $\mathrm{T}$ cells in gut and respiratory mucosa [62].

Immunophenotyping analysis of fatal and survivor blood samples indicated activation of CD8 ${ }^{+}$ and $\mathrm{CD} 4^{+} \mathrm{T}$ cells. Still, the magnitude and diversity of the immune response induced in the survivors were more robust as compared to fatal cases. Proliferation of T cells and yet their failure to effectively protect against EVD in fatal cases may be attributed to either a state of T-cell exhaustion $[58,63,64]$ or little and delayed proliferation in some cases owing to exaggerated viral count and uncontrolled viral replication $[28,56]$. Additionally, activation of $\mathrm{Ki}-67^{+} / \mathrm{PD}-1^{+} \mathrm{CD} 8^{+} \mathrm{T}$ cell subset seems responsible for a weaker adaptive immune response via PD-1 inhibitory pathway [56]. Indeed, oligoclonal response and greater expression of CTLA- 4 and PD- 1 in CD8 ${ }^{+}$and CD4 ${ }^{+}$T cells was found in fatal cases, which could explain the high virus titer as well as T-cell exhaustion $[58,62,63,65,66]$. Whether the high viral titers and inflammation could cause a greater CTLA- 4 and PD- 1 expression on T cells in fatal cases remains unclear [58].

\subsubsection{Lymphocyte Apoptosis}

A massive reduction of lymphocyte $\left(\mathrm{CD}^{+}, \mathrm{CD} 4^{+}\right.$and NK cells) counts was found in the initial as well as the end stages of fatal EVD [67]. Experimentally infected NHP models displayed a reduction in peripheral NK cell count which may be attributed to apoptosis [68]. CD8 ${ }^{+}$and $\mathrm{CD} 4^{+}$cells appear to be the most affected as their counts in fatal cases were found reduced to an approximately one fourth their number in survivors [23]. Expression analysis of $\mathrm{CD} 95$ for $\mathrm{CD} 8^{+}$and $\mathrm{CD} 4^{+} \mathrm{T}$ cells as well as PD-1 for $\mathrm{CD} 4^{+} \mathrm{T}$ cells in EVD patients suggested the role of apoptotic pathways in massive lymphocyte loss [69]. Lymphocyte apoptosis could be attributed to (a) deregulation of DC/T interaction, i.e., lack of co-stimulatory rescue signals by malfunctioning DCs or (b) upregulation of apoptotic genes such as Fas, Fas Ligand (FasL) and tumor necrosis factor (TNF)-related apoptosis-inducing ligand (TRAIL) 
in infected leukocytes or (c) Direct lysis by EBOV GP [23,67,70]. Indeed, excess TNF- $\alpha$ secretion is thought to contribute to lymphocyte apoptosis in NHP models [71].

However, bystander T-cell apoptosis doesn't seem to be a definite EVD characteristic and as such, does not seem to indicate fatality. This is supported by a report that EBOV caused death in apoptotic gene knockout mice despite reduced $\mathrm{T}$ cell apoptosis [72]. Additionally, T cells produced in experimentally EBOV infected mice were found to protect naive mice upon adoptive transfer [73] while complete depletion of T cells in experimentally infected NHP led to an increased fatality rate [59] suggesting a significant role of $\mathrm{T}$ cells in host survival. Similar data was demonstrated using mice deficient in cytotoxic $\mathrm{T}$ cells $\left(\mathrm{T}_{\mathrm{C}}\right.$ cells), where mice were dying upon experimental EBOV infection [74].

Overall, various reports suggest a critical, though highly varied role of $\mathrm{T}$ cells/cell mediated immune response upon EBOV infection in both, fatal and survivor cases and therefore, the actual lymphocyte apoptosis mechanism, T cell immunity dynamics and behavior during EVD is vital to understanding EBOV pathology.

\subsection{The Cytokine Storm}

Multiple studies indicate a surge in procoagulant tissue factor protein, oxygen free radicals, cytokines and chemokines upon EBOV infection which could lead to a severe disease and death [75-79]. Exact mechanisms behind the early cytokine storm are unclear as in vitro analysis of infected human DC and macrophages indicated the restriction in their ability to secrete the immune mediators [80]. Elevated levels of several cytokines were found in macrophages infected with EBOV even before detection of viral gene expression, indicating a role of EBOV GP in inducing the inflammation [81]. Another in vitro study has reported that shed GP is capable of binding to uninfected mononuclear phagocytes via TLR4 receptors and contributing to the cytokine production [82].

Intracellular cytokine assay analysis revealed the production of IFN $-\gamma$ by CD8 ${ }^{+} \mathrm{T}$ cells in EBOV infected mice [73]. Additionally, in another study using a mouse model, EBOV was shown to infect $\mathrm{CD}^{+} \mathrm{T}$ cells without replication, while inducing cytokine release [79]. A "superagonist-like" effect regarding NFAT signaling pathway activation was demonstrated upon binding of EBOV to CD4 ${ }^{+}$ T cells, enabling these leukocytes to secrete IFN- $\gamma$, IL-2, TNF- $\alpha$ and IL-8 [79]. Similarly, analysis of human peripheral blood mononuclear cells (PBMCs) obtained from convalescent EBOV patients indicated high IFN- $\gamma$ secretion by $\mathrm{CD} 8^{+} \mathrm{T}$ cells [56]. Though $\mathrm{CD} 4^{+} \mathrm{T}$ cells were found less capable of secreting IFN- $\gamma$ than $\mathrm{CD} 8^{+} \mathrm{T}$ cells, still, the majority of such $\mathrm{CD} 4^{+} \mathrm{T}$ cells were also secreting IL-2 and TNF- $\alpha$ [56]. Therefore, a combined effect of virus affected macrophages and activated T cells along with uncontrolled viral replication has been contemplated as a plausible reason for massive pro-inflammatory cytokine production [79].

Increased levels of IL-1 $\beta$, IL-6, IL-10, IL-15, IL-16, TNF- $\alpha$, IFN- $\alpha$, IFN- $\beta$, IFN- $\gamma$, NO, MIP-1 $\alpha$, MIP-1 $\beta$, MIF and IP-10 are primarily demonstrated in EVD cases [83,84]. Increased IL-10 and TNF- $\alpha$ levels are universally accepted as EVD fatality indicators whereas association of increased NO, IFN- $\alpha$, IFN- $\gamma$, IP-10, IL-12, IL-17 and IL-6 levels with fatality has mixed recognition [18,23,85-87]. An early IFN- $\gamma$ response followed by an extensive lymphocyte apoptosis is an accepted fatality indicator [23,83], whereas high IFN- $\beta$ serum levels could indicate lower disease severity [17]. Higher expression of CTLA- 4 in T cells corresponded to presence of greater TNF- $\alpha$ and IL- 8 quantities in fatal cases. Additionally, serum levels of certain chemokines, such as MIP- $1 \alpha$, MIP-1 $\beta$ and MCP1, were substantially higher in fatal EVD cases [58]. It appears that an increased levels of MIP- $1 \alpha$ and IP-10 are associated with hemorrhages, which could lead to a serious complications and death in EVD (reviewed in [23]). Though early and short-lived IFN- $\alpha$ production has been related to survival [88], it appears that the virus can counteract it (discussed in Section 4).

\subsection{Interplay between Cytokines and Coagulation Factors}

As discussed, severe infection leads to hyperproduction of proinflammatory cytokines. These cytokines activate coagulation factors such as thrombomodulin, ferritin etc. [23]. A study 
reported upregulation of procoagulant protein tissue factor in endothelial cells and monocytes by TNF- $\alpha$ and IL-6 [89]. The released coagulation factors in turn upregulate proinflammatory cytokines. Studies have suggested that fibrin fragment $\mathrm{E}$ and thrombin induce IL-6 production in monocytes while thrombin induces IL-6 and IL-8 production in endothelial cells $[18,90]$. Hence, a deadly chain reaction ensues upon filoviral infection which culminates into shock, vascular damage and homeostatic imbalance.

\subsection{Endothelial Cell Dysfunction and Vascular Damage}

Endothelial cells seem to be directly infected during terminal stages of EBOV infection due to over expression of proinflammatory cytokines but do not seem to exhibit any structural damage [18,28]. EBOV GP, supported by TNF- $\alpha$, is thought to play a pivotal role in endothelial cell dysfunction, consequently, leading to anoikis and hemorrhage [23,91-93]. A study during 1995 outbreak found antigens in endothelial cells in different body tissues [94]. A recent study supported endothelial dysfunction on basis of increased thrombomodulin, P-selectin and PE-CAM (all are markers of endothelial activation and dysfunction) in patients [28,50]. However, the precise timing and consequences of endothelial cell dysfunction are yet to be elucidated. An early study reported no antigen presence in endothelial cells [95]. Additionally, antigen multiplication in vascular endothelial cells in later stages (after appearance of hemorrhage) upon experimental EBOV infection of cynomolgus monkeys has been reported $[18,26]$.

Disseminated intravascular coagulation (DIC) coupled with low platelet count as well as coagulation factor deficiency is known to occur during EBOV infection [96]. It has been debatably related to endothelial cell disorders, especially release of thrombomodulin by activated endothelial cells $[18,28,84]$. Various reports attribute the endothelial cell activation and consequent dysfunction as well as vascular damage to (a) release of proinflammatory cytokines [75,77,97], especially TNF- $\alpha$ [98,99] and NO [87] or (b) overexpression of cell surface tissue factor in monocytes and macrophages [26] or (c) elevated levels of Von Willebrand factor (vWF), a protein which acts as mediator between platelets and endothelial cells [28].

\subsection{Humoral Immune Response}

Although cell-mediated immunity is suggested to play the leading role in protection against EBOV infection [17], humoral immunity, such as production of antibodies coupled with $\mathrm{T}_{\mathrm{c}}$ activation (via Fas/FasL or perforin pathway) is suggested to be a credible marker of survival [23,56]. EBOV-specific IgM and IgG antibodies are detected nearly 12-31 days and $23-42$ days post infection, respectively $[56,86]$. Humoral response is thought to play a lesser role in EVD survival as susceptibility to infection and recovery in mouse models was independent of humoral response [74]. Additionally, no difference in antibody titers was found in survivors and fatal cases during the outbreak [100]. Little role of neutralizing antibodies $\left(\mathrm{N}_{\mathrm{Ab}}\right)$ in recovering from acute stages, attributed to the need for high diversity in $\mathrm{N}_{\mathrm{Ab}}$ repertoire and to a lack of early $\mathrm{B}$ cell affinity maturation, has been reported during the course of infection $[28,56,101,102]$. In another report, some fatal cases have been recorded despite the presence of antibodies while several survivors did not develop IgG [103].

\section{Evasion of Host Immune Response by EBOV}

Multiple studies have demonstrated that EBOV employs an array of mechanisms to effectively evade the host immune responses (Figure 2), where viral GP, VP24, VP35 and VP40 play a significant role (reviewed in [104]). The efficacy of host immune evasion by EBOV is indicated by the rapid replication rate displayed by the virus inside the host cells [27]. VP35 and VP24 can interfere with the host antiviral defense system by restricting early IFN production and signaling (reviewed in [105]). VP35 and VP24 regions responsible for virus protection against host antiviral activity are called innate response antagonist domains (IRADs) [105]. 


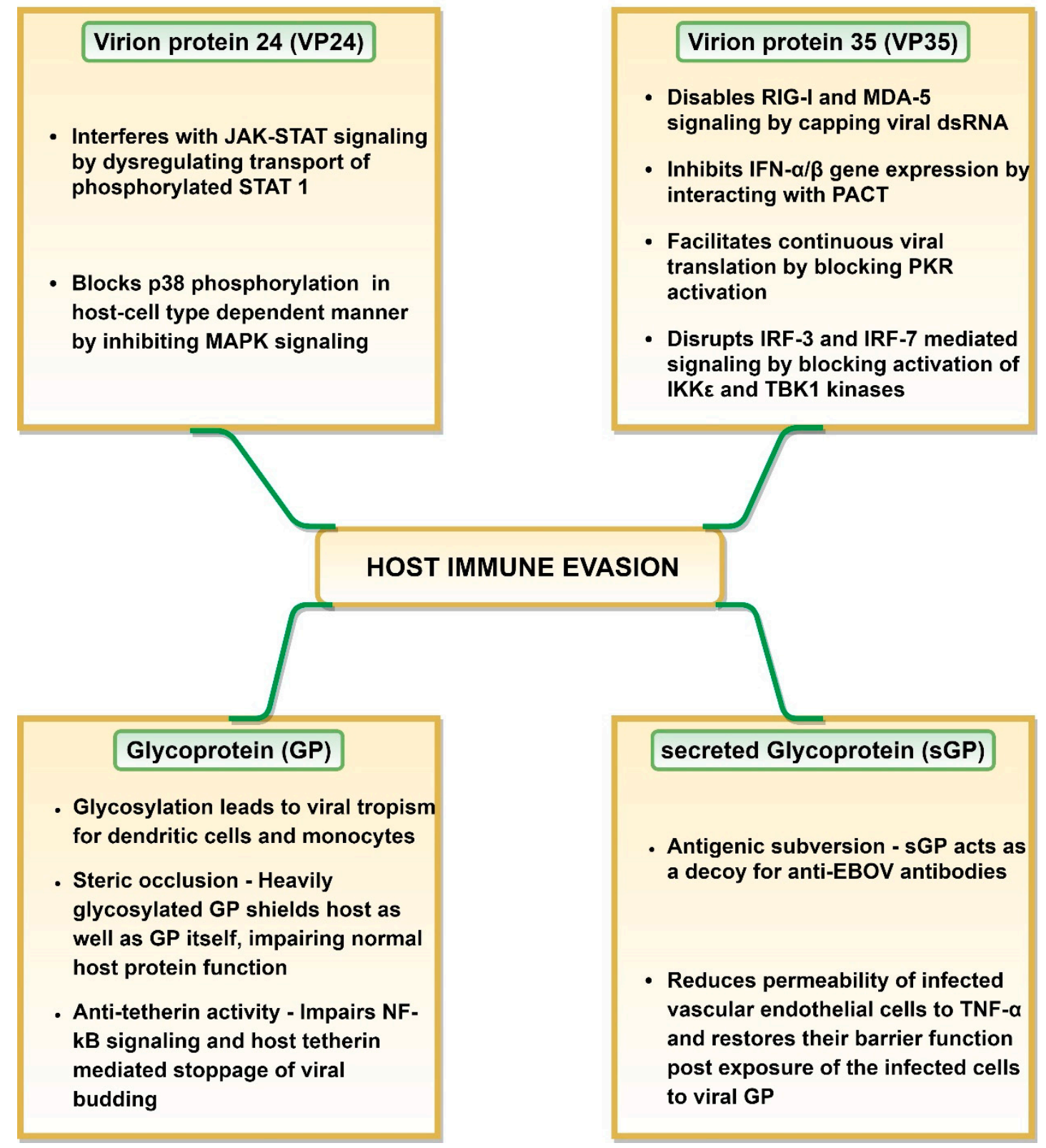

Figure 2. Mechanisms of host immune evasion employed by Ebola virus.

VP24 can bind to specific members of karyopherin alpha (KPNA) family proteins involved in nuclear translocation of phosphorylated signal transducer and activator of transcription 1 (STAT 1) [106]. This could be explained by the fact that the binding affinity of VP24 to KPNA is significantly higher than that of phosphorylated STAT 1 [106]. It renders karyopherin- $\alpha 1$ incapable of transporting phosphorylated STAT 1 across the nuclear pore to activate gene transcription. This results in interference with the type I and II IFN response by restricting the JAK-STAT to the cytoplasm [105,107,108] (Figure 2). However, EBOV, SUDV and TAFV inhibit IFN-signaling with greater efficacy as compared to BDBV and RESTV, a feature attributed to high KPNA binding ability of the former viruses [104,109]. A host cell-type dependent restriction of IFN signaling through mitogen-activated protein kinases (MAPK) pathway by VP24 has also been reported $[105,110]$. VP24 was shown to block p38 phosphorylation in human embryonic kidney 293 (HEK 293) cells but not in HeLa cells, resulting in blockage of MAPK pathway only in these cells $[105,110]$ (Figure 2).

VP35 plays a central role in host immune response evasion (Figure 2). Inhibition of type I IFN production by VP35 is a pan-filovirus characteristic [104]. VP35 effectively shields dsRNA from 
detection during replication/transcription stage [105]. It caps dsRNA via Phe235 and Phe239 residues and thus, prevents host retinoic acid-inducible gene I (RIG-I) and melanoma differentiation-associated protein 5 (MDA-5) from identifying viral dsRNA [111,112]. VP35 can also block host protein activator of the interferon-induced protein kinase (PACT) protein activation in RNA-independent manner, in effect cutting off RIG-I or MDA-5 signaling and IFN- $\alpha / \beta$ gene expression $[108,113]$. Interestingly, the same VP35 carboxy-terminal domain (residues 220-340) is involved in capping the ends of dsRNA, VP35-dsRNA interaction (especially basic residues such as Arg312, Lys319 and Arg322) and VP35-PACT interaction (especially residues Arg312, Arg322 and Phe239) [112-114]. Due to the first two functions, this VP35 carboxy-terminal domain is also known as interferon inhibitory domain (IID) as it shields dsRNA from host cellular sensors [105,108]. This domain is involved in restriction of the RIG-I ATPase and IFN- $\beta$ promoter activity [104]. Additionally, VP35 IID domain, especially Arg305, Lys309 and Arg312 residues prevent dsRNA-dependent protein kinase R (PKR) activation in dsRNA-binding independent manner. This blocks eukaryotic translation initiation factor $2 \alpha(\mathrm{eIF} 2 \alpha)$ phosphorylation, thus, enabling continuation of viral protein synthesis [104,115,116] (Figure 2).

VP35 can also block activation of IKK $\varepsilon$ and TBK1 kinases by interacting with their conserved domains [117]. This, in effect, blocks IRF-3 and IRF-7 phosphorylation by IKK $\varepsilon$ and TBK1 kinases. Prevention of IRF-3 phosphorylation could hamper IFN production, as this transcription factor is essential for induction of IFN- $\beta$ promoter [117]. Additionally, VP35 has the ability to increase IRF-3/7 SUMOylation [118]. Both mechanisms prevent IRF-3 and IRF-7 mediating signaling and the subsequent IFN $\alpha / \beta$ gene expression $[108,119,120]$.

The suppression of an innate immune response by VP35 has far reaching consequences. It impairs RIG-I-like receptor (RLR) signaling resulting in lack of DC maturation which restricts IFN- $\alpha / \beta$ and cytokine production as well as $\mathrm{T}$ cell activation $[108,121]$. This ultimately impedes $\mathrm{T}$ cell response and may lead to a collective failure of an adaptive immune response (reviewed in [108]). Interestingly, blocking DC activation requires IRAD of both, VP35 and VP24 (reviewed in [105]).

It appears that secreted glycoprotein (sGP) could also contribute to the immune response evasion by acting as a decoy for anti-EBOV antibodies. Mohan and coworkers demonstrated that sGP can function as a roadblock between the virus GP and anti-GP 1,2 antibodies as it can effectively compete for these antibodies [122]. This could prevent the interaction between antibodies and the virus GP and lead to antigenic subversion [122]. Additionally, GP1 glycosylation, although not required for the virus entry, could protect GP from immune recognition, thus, enabling binding to the host cell [123]. An interesting role of sGP in host leukocytes evasion was postulated by Wahl-Jensen et al., reporting that sGP decreased the permeability of infected vascular endothelial cells to TNF- $\alpha$ as well as restored their barrier function post exposure of the infected cells to viral GP [93].

EBOV GP can interfere with immune recognition of HLA class I and II molecules, a phenomenon termed as "steric occlusion" [124]. Not only does this occur on host cells, steric occlusion also prevents the recognition of EBOV GP [124]. Therefore, steric occlusion could be another way in which virus can elude the host immunity. EBOV GP also has the anti-tetherin activity, thus, disabling the stoppage of VP40-mediated viral budding by host cell tetherin as well as disabling the immune response stimulation via NF-kB signaling [125,126] (Figure 2).

\section{EBOV: Prevention and Control}

\subsection{Vaccine Development against EBOV}

The first vaccine candidates against EBOV were tested in the 1970s and 1980s which were based on immunization with an attenuated virus [127]. Lack of efficacy and concern for safety led to consideration of an alternative approach using DNA vaccines in the 1990s [128]. In recent years, multiple approaches were used to design an anti-EBOV vaccine which included various vectors such as alphavirus replicons [129-131], virus-like particles [132], human adenoviruses (Ad) [133-135], a biologically contained EBOV lacking VP30 [136], chimpanzee adenovirus [137], 
DNA [138], paramyxoviruses [139,140], cytomegalovirus (CMV) vectors [141], rabies virus [142,143], modified vaccinia virus Ankara (MVA) [144] and different strategies with recombinant vesicular stomatitis virus (rVSV) $[145,146]$ (Table 1).

Table 1. Vaccines development against Ebola virus under consideration and their clinical trial phase.

\begin{tabular}{|c|c|c|c|c|}
\hline Vaccine & Responsible Party & Location & Clinical Trial Phase & References \\
\hline INO-4212 & Inovio Pharmaceuticals & United states & I & [147] \\
\hline rChAd3-EBOS & NIAID & Uganda & I & [148] \\
\hline $\begin{array}{c}\text { DNA plasmid vaccine } \\
\text { (VRC-EBODNA012-00-VP) }\end{array}$ & NIAID & United states & I & {$[149,150]$} \\
\hline HPIV3-EBOVZ GP & NIAID & United states & $\mathrm{I}$ & [151] \\
\hline HPIV3/AHNF/EbovZ GP & NIAID & United states & I & [152] \\
\hline ChAd3-EBO-Z + Ad26.ZEBOV & University of Oxford & United Kingdom & I & [153] \\
\hline rVSVN4CT1-EBOVGP1 & Auro vaccines LLC & United states & I & {$[146]$} \\
\hline rChAd3-EBOV + MVA BN-Filo & University of Oxford & Senegal & I & [154] \\
\hline rAd5-EBOV & $\begin{array}{l}\text { Sierra Leone-China } \\
\text { Friendship Hospital }\end{array}$ & Sierra Leone & II & [155] \\
\hline rChAd3-ZEBOV & GlaxoSmithKline & Mali and Senegal & II & {$[156,157]$} \\
\hline $\begin{array}{l}\text { rAd26-EBOV + MVA-BN-Filo + } \\
\text { rVSV } \triangle \text { G-ZEBOV-GP }\end{array}$ & NIAID & $\begin{array}{c}\text { Guinea, Liberia, } \\
\text { Mali and } \\
\text { Sierra Leone }\end{array}$ & II & [158] \\
\hline VSVG-ZEBOV + ChAd3-EBO Z & NIAID & Liberia & II & [159] \\
\hline MVA-BN Filo + rAd26-EBOV & $\begin{array}{l}\text { London School of Hygiene } \\
\text { and Tropical Medicine }\end{array}$ & DRC & III & [160] \\
\hline GamEvac-combi vaccine & $\begin{array}{c}\text { Gamaleya Research } \\
\text { Institute of Epidemiology } \\
\text { and Microbiology }\end{array}$ & $\begin{array}{l}\text { Guinea and } \\
\text { Russian Federation }\end{array}$ & IV & {$[161,162]$} \\
\hline
\end{tabular}

The rVSV vector based EBOV vaccine candidates are considered as having a high protective potential (Table 1). rVSV vector based vaccines can be administered via mucosal membrane [163] and are highly immunogenic $[164,165]$ as proven in NHP models where a robust and protective cell mediated immune response was demonstrated when lethal dose of virus was used [145]. Another study reported complete protection of NHPs even when vaccine was used three months after Lassa virus VSV-based vaccine administration indicating there are no pre-existing immunity concerns to rVSV [166,167]. Indeed, a recombinant live-attenuated VSV vector based vaccine expressing EBOV GP was FDA approved on 19 December 2019 for individuals $\geq 18$ years age [168,169]. Merck Sharp and Dohme Corp. received the authorization to market a single dose vaccine, under the tradename Ervebo [169]. Ervebo vaccine induces antibody response and CD8 ${ }^{+}$T-cell activation upon administration [168], though the efficacy of resultant antibodies in viral clearance needs further analysis. Before FDA approval of Ervebo vaccine, Farooq et al., reported a role of circular follicular T helper cells upon injection of rVSV-ZEBOV-GP vaccine candidate in human subjects [170]. A correlation between the frequency of circulating CXCR5 ${ }^{+} \mathrm{CD} 4^{+}$T-cells and antibody titers was also recorded [170].

Another approach for EBOV vaccine development includes a combination of MVA-BN Filo and rAd26-EBOV [171]. The combination was shown to be well tolerated, capable of activating $\mathrm{CD}^{+}$and $\mathrm{CD}^{+}$cell responses as well as generated viral neutralizing antibodies [171]. Additionally, this combination is currently in phase III clinical trials [160] (Table 1). The only vaccine candidate currently in phase IV clinical trials is a GamEvac-combi vaccine which consists of live-attenuated rVSV and Ad5-EBOVGP [161] (Table 1). This vaccine could activate CD8 ${ }^{+}$and CD4 ${ }^{+} \mathrm{T}^{-}$cells which could explain its efficacy [162].

Another vaccine candidate is developed by removing the VP30 gene (EBOVDVP30) from EBOV genome [172,173]. This recombinant virus is replication incompetent, yet it was shown to be safe and can induce a robust immune response in NHP [136]. Wild type as well as $\mathrm{H}_{2} \mathrm{O}_{2}$ treated EBOV $\triangle$ VP30 vaccine conferred complete protection via producing high antibody titers directed 
against various viral proteins [136]. Production of IFN- $\gamma$ producing mononuclear cells was also suggested though their significance and impact was not reported [136]. Another vaccine candidate, MVA based, replication-incompetent, modified to express EBOV GP and VP40 proteins has conferred $100 \%$ protection in guinea pig and macaque models against lethal EBOV infection and has currently entered clinical trials [144].

Rabies virus (RABV) infection has been observed in many regions endemic for EBOV infection [174]. Hence, it could be suggested that the recombinant RABV based vector vaccine could be used to protect against both, EBOV and RABV infection. RABV vector based vaccine was reported to induce complete protection by eliciting strong humoral immune response in NHP infected with EBOV when a single dose was used [142]. Modification of the inactivated RABV vaccine vector using a codon-optimized antigen [143] and use of adjuvants was also protective [175]. This strategy is moving forward to being tested in clinical trials [175].

Peptide based vaccines have emerged as alternative candidates which display improved safety, specificity, selectivity and stability. Antigenic peptides, containing immunogenic epitopes, represent the minimum requirement for recognition of pathogen by immune system and are capable of inducing a strong immune response (reviewed in [176]). In efforts to identify potential epitopes, computational prediction of $\mathrm{H}-2 \mathrm{~d}$-specific $\mathrm{T}$ cell epitopes and their identification in $\mathrm{BALB} / \mathrm{c}$ mice infected with replication-incompetent, ebolavirus GP expressing adenovirus vectors was done for Sudan ebolavirus and Zaire ebolavirus [177]. This study identified RPHTPQFLF, GPCAGDFAF and LYDRLASTV as potentially immunogenic peptides in mice model [177]. In 2015, 28 ebolavirus 9-mer epitopes with no apparent human homologs were identified using computer based approach [178]. Additionally, TLASIGTAF peptide was identified as a highly potent $B$ and T cell activating epitope with the ability to be a part of epitope-based vaccine as it showed positive interaction with 12 HLA alleles and population coverage of $80.99 \%$ [179]. Later, computational identification of highly conserved peptides containing T and B cell epitopes in GP as well as NP non-redundant sequences belonging to all reported strains of ebolaviruses infecting humans was done by our research group [180,181]. In silico selected NP peptides showed enhanced IFN- $\gamma$ production in most of the blood samples in vitro [181].

To summarize, the vaccine approaches discussed so far present specific advantages. Non-replicating vectors such as Ad5 and EBOV $\triangle \mathrm{VP} 30$ are considerably safer than replication-competent vectors (reviewed in [182]). rVSV vector-based vaccines are highly immunogenic and seem to be devoid of pre-existing immunity concerns [145,167]. A combination of MVA-BN Filo and rAd26-EBOV seems capable of generating both, cell mediated and humoral immune response [171]. $\mathrm{H}_{2} \mathrm{O}_{2}$ treated EBOV $\Delta V P 30$ vaccine candidate addresses the earlier safety concerns and has exhibited high experimental efficacy [182] while recombinant rabies virus-based vector offers an opportunity to fight against two diseases (rabies and EBOV) endemic to same geographical regions [174]. Peptide-based vaccines offer a safer, economical and faster approach to counter the rapidly increasing threat of endemic pathogens [176].

These vaccine development approaches also suffer from different limitations (reviewed in [183]). Production difficulties and high cost are the major limitations of using the VLP platform [182]. DNA vaccines require regular booster dosages (reviewed in [184]). Pre-existing immunity against adenovirus based vectors and consequently, low efficacy, presents a major concern [185]. Low immunogenicity and in vivo peptide instability are major challenges while designing peptide-based vaccines [176].

\subsection{Post-Exposure Therapeutics Development against EBOV}

The constant EBOV infection threat and highly contagious nature of the infection make the search for post-exposure therapeutics especially important. The need for EBOV therapeutics was further signified after the 2014 outbreak when WHO permitted the use of untested drugs to control the high death rate (reviewed in [186]). Currently, 80 drugs with anti-EBOV activity are consented by the FDA (reviewed in [187]). A brief summary of various works done with respect to therapeutics development is presented in Table 2. 
One of the therapeutic approaches involves recombinant nematode anticoagulant protein c2 (rNAPc2) which helps combat the thrombin-related organ failure. In a study, only one third of the total EBOV exposed Rhesus macaques survived upon administration of rNAPc2, indicating only partial and limited protection elicited by rNAPc2 [188]. In Dec 2014, FDA granted orphan drug status to rNAPc2 and recommended it as post-exposure treatment [189] despite the limitations such as need for repeated dosages and low efficacy [190]. rNAPc2 has passed phase II clinical trials [190].

The therapeutic efficacy of the small RNA (sRNA) molecules was also tested using NHP model of EBOV infection. TKM-100802, a small RNA-interfering (siRNA) molecule targeting VP35 and L genes, was administered to NHP 30 min prior EBOV infection [191]. Protection was conferred in $100 \%$ animals which received a total of six doses during six consecutive days [191]. The same drug proved highly effective when given to EVD patients in Europe and US; however, no conclusive result could be declared as the patients received an additional therapeutics simultaneously [192]. TKM-130803 was formulated by modification of TKM-100802 to increase the drug efficacy towards the specific strain responsible for 2014-2016 EBOV outbreak [193]. However, this drug failed to increase the survival rates of EVD patients [193].

AVI-6002, a combination of 2 phosphorodiamidate morpholino antisense oligomers with piperazine residues along the oligomeric backbone, was designed to target EBOV VP35, VP24 and L proteins [194]. This drug showed 60\% efficacy in NHP EBOV infection model [194] (Table 2). Additionally, it was well tolerated during phase I clinical trials $[195,196]$. Another drug was developed by BioCryst Pharmaceuticals, targeting L protein [197]. This drug is an adenosine analog named BCX4430 which is a non-obligate RNA-chain terminator [197]. BCX4430 has shown encouraging results in EBOV infected mice as well as NHP [197]. It also completed phase I clinical trials in 2016 (CT: NCT02319772). Dismal pharmacokinetic properties and short half-life of BCX4430 are the major drawbacks while on the upside, it did not become incorporated into the host DNA [196,197]. Another nucleoside drug capable of inhibition of viral RNA synthesis is Favipiravir (Table 2), which is produced by modification of pyrazine [198]. Favipiravir was shown effective in mice [199]; however, only decreased virus titer was reported when used to treat EBOV in NHP model [200]. Therefore, this drug is approved only for the compassionate use by the French drug safety agency [201].

Remdesivir or GS-5734 had 100\% protection in NHP when administered $72 \mathrm{~h}$ post EBOV infection [202] (Table 2). This drug was used as an emergency drug in both, 2014-2016 epidemic and the 2018 DRC epidemic [203,204]. Remdesivir cleared phase II clinical trials in 2019 (CT: NCT02818582) and is currently a part of phase II/III multi-therapeutic investigation trial (CT: NCT03719586). However, despite experimental success, low efficacy in human trials has been observed [205].

Compound 7, a benzodiazepine derivative, was shown to bind directly to EBOV GP in cell culture, preventing EBOV entry [206]. Other compounds viz., NSC62914 (a reactive oxygen species) and LJ001 (a rhodanine derivative) have shown anti-EBOV activity in vitro and in mouse model $[207,208]$. Additionally, Tolcapone (a FDA approved drug) impaired EBOV replication in vitro while 3-deazaneplanocin A (a carbocyclic nucleoside) and FGI-103, FGI-104 and FGI-106 (broad-spectrum antiviral agents) were shown to protect EBOV infected mice [209-212].

Some compounds such as Benzylpiperazine adamantane diamides, Arbidol, wortmannin, rottlerin and latrunculin A were shown to act as virus entry inhibitors [196,204]. Clomiphene and toremifene were identified as EBOV entry inhibitors in vitro and protected $90 \%$ and $50 \%$ mice, respectively $[204,213]$.

Other compounds with anti-EBOV efficacy include pradimicin $\mathrm{A}$ and benanomicin $\mathrm{A}$, which are non-peptidic antibiotics that target ebolavirus GP (reviewed in [214]). Enzon Pharmaceuticals provides commercial-grade human mannose-binding lectin (MBL), a C-type lectin that identifies various ebolavirus surface glycan structures, such as glucose, mannose etc. (Table 2). Griffithsin (GRFT) is a red algae derived lectin which is devoid of mitogenic activity and interacts with the terminal mannose molecules of N-linked glycans on the outside of ebolavirus [215]. In contrast to many lectins, GRFT has limited effect on proinflammatory cytokine production in PBMC, has low toxicity and can be produced on a large scale [215] (Table 2). 
Table 2. Therapeutic drug development measures against Ebolaviruses.

\begin{tabular}{|c|c|c|c|c|c|}
\hline Drug Name & Nature & Responsible Party, Location * & Target & Clinical Trial Phase/Efficacy & Reference \\
\hline Mannose-binding lectin (MBL) & $\begin{array}{l}\text { Carbohydrate-binding protein } \\
\text { (or lectin) }\end{array}$ & - & GP & $40 \%$ in mice & [216] \\
\hline Griffithsin (GRFT) & $\begin{array}{l}\text { Carbohydrate-binding protein } \\
\text { (or lectin) }\end{array}$ & - & Glycan structures & - & [215] \\
\hline BCX4430 & Adenosine analog & $\begin{array}{l}\text { BioCryst Pharmaceuticals, } \\
\text { United States }\end{array}$ & RNA polymerase & I & {$[197,217]$} \\
\hline T-705 (Favipiravir) & Pyrazinecarboxamide derivative & $\begin{array}{l}\text { Institut National de la Santé Et de } \\
\text { la Recherche Médicale, Guinea }\end{array}$ & RNA polymerase & II & [218] \\
\hline Aptamers & Oligonucleotide & - & VP35 & - & [219] \\
\hline AVI-6002 (PMO) & $\begin{array}{l}\text { Phosphorodiamidate } \\
\text { Morpholino Oligomer }\end{array}$ & $\begin{array}{l}\text { Sarepta Therapeutics, Inc., } \\
\text { United States }\end{array}$ & VP24 and VP35 & $\mathrm{I} / 60 \%$ in NHP & {$[194,220]$} \\
\hline TKM-100802 & Small interfering RNA & $\begin{array}{c}\text { Arbutus Biopharma Corporation, } \\
\text { United States }\end{array}$ & RNA polymerase and VP35 & Trials terminated $/ 100 \%$ in NHP & {$[191,221]$} \\
\hline Small molecule inhibitor of VP40 & - & - & VP40 & - & [222] \\
\hline GS-5734 & Adenosine triphosphate analog & NIAID, Guinea and Liberia & RNA synthesis & $\begin{array}{l}\mathrm{II} / 100 \% \text { in NHP when administered } \\
72 \mathrm{~h} \text { post infection }\end{array}$ & {$[202,223]$} \\
\hline 3-Deazaneplanocin A & Carbocyclic nucleoside & - & RNA synthesis & $\begin{array}{l}100 \% \text { in BALB/c mice when } \\
\text { administered } 48 \mathrm{~h} \text { post infection }\end{array}$ & [212] \\
\hline Mab114 & Monoclonal antibody & NIAID, United States & GP & Safe and well tolerated in phase I trial & [224] \\
\hline MB-003 & Monoclonal antibody cocktail & - & GP & $\begin{array}{l}120 \text { h delayed intervention protected } \\
40 \% \text { NHP }\end{array}$ & [225] \\
\hline U18666A & Cationic sterol & - & ebolavirus-NPC1 interaction & Almost $100 \%$ efficacy in vitro & [38] \\
\hline $\mathrm{ZMAb}$ & Monoclonal antibody cocktail & - & GP & $\begin{array}{l}100 \% \text { in NHP given three doses in six } \\
\text { days starting } 24 \mathrm{~h} \text { after infection }\end{array}$ & [226] \\
\hline ZMapp & Monoclonal antibody cocktail & $\begin{array}{l}\text { NIAID, United States, Guinea, } \\
\text { Liberia and Sierra Leone }\end{array}$ & GP & $\begin{array}{c}\text { Completed phase } \mathrm{I} / 100 \% \text { in NHP } \\
\text { when administered five days } \\
\text { post-infection }\end{array}$ & [227] \\
\hline MIL77E & Monoclonal antibody cocktail & - & GP & $\begin{array}{l}100 \% \text { in NHP when give } 72 \mathrm{~h} \\
\text { post infection }\end{array}$ & [228] \\
\hline
\end{tabular}

* Responsible party is the collaborator responsible for clinical trial. Location specifies the area where clinical trial (if any) was conducted. In case no clinical trial has been reported as yet, no responsible party or location has been mentioned. 
Antibodies are known to inhibit viral entry as well as facilitate the antibody-directed cell-mediated cytotoxicity by NK cells (reviewed in [229]). Additionally, together with the complement system, antibodies can neutralize the virus [229]. Therefore, EVD convalescent plasma (CP) containing polyclonal EBOV specific IgG have a potential to inhibit virus replication and dissemination [230]. Additionally, this approach presents a feasible and safe way for EVD treatment during an outbreak [230]. $\mathrm{CP}$ could also help to manage the blood loss commonly found in EVD [231]. CP administration was used alongside other treatments the UK researcher, who had contracted the disease while working with samples collected during the 1976 outbreak [232] as well as for 8 cases during Kitwit outbreak in 1993 [231]. In the latter case, seven patients survived but conclusive evidence of CP efficacy is lacking as other treatments such as antibiotics, antipyretics, oral rehydration and chloroquine were also used [232]. During 2014-2016 outbreak, a phase II/III trial (CT: NCT02342171) was conducted to determine the efficacy of $\mathrm{CP}$ in Guinea where $84 \mathrm{EVD}$ patients received up to $500 \mathrm{~mL} \mathrm{CP}$ along with the standard of care (SOC) treatment [230]. Although, clinically significant difference was not found between these patients and 418 control group (EBOV patients receiving SOC only), the survival rate was found higher when $\mathrm{CP}$ was the part the patient management protocol [230]. Limitations of $\mathrm{CP}$ include pre-screening requirement for blood transmitted pathogens, transfusion reactions, $\mathrm{CP}$ harvest timing, toxicity related problems and lot-to-lot variations $[47,232,233]$, which directed researchers towards developing monoclonal antibodies.

Monoclonal antibodies (mAb) are IgG antibodies produced by a single B cell clone that could help to control virus spread by targeting EBOV GP (reviewed in [190,234]). A human convalescent monoclonal antibody, KZ52, was shown to be effective in mouse models; however, it failed in protecting NHPs from EBOV infection even when injected one day prior to exposure [235]. Another mAb, MAb114, is human mAb isolated during the Kitwit outbreak in 1993 [236]. Though it conferred protection in NHP when administered $120 \mathrm{~h}$ post lethal EBOV infection, viremia and clinical signs were still present [234]. These symptoms were shown to be reduced by administering a cocktail of mAb114 and mAb100, another mAb isolated from same survivor [234] (Table 2). mAb114 had cleared phase I clinical trials (CT: NCT03478891) in 2019 and is currently in phase II/III clinical trials (CT: NCT03719586).

MB-003 is a cocktail of mAb developed by the US Army Medical Research Institute of Infectious Diseases and consists of three murine mAbs (13C6, 6D8 and 13F6) against EBOV GP [232]. After encouraging results using mouse model [237], the therapeutic efficacy of this cocktail was tested in NHP, where two third of animals survived the EBOV infection [238]. Additionally, the therapeutic efficacy of MB-003 was confirmed when used five days post infection, protecting $40 \%$ of NHP [225] (Table 2).

ZMAb, developed by the Public Health Agency of Canada, includes three murine mAbs (1H3, 2G4 and 4G7) [239]. In NHP model, ZMAb conferred $100 \%$ protection when animals received three doses of the drug in six days starting $24 \mathrm{~h}$ after infection [226] (Table 2). To check if any immune response was developed in NHP treated and recovered, they were infected again 2.5 months post first infection. All the macaques survived the second EBOV challenge, suggesting the presence of an immune protection for months after the ZMab treatment [240]. Combined treatment with ZMAb cocktail administered $96 \mathrm{~h}$ post infection followed by AD5-IFN $\alpha$ injected $24 \mathrm{~h}$ post infection was also effective in $50 \%$ NHP [241]. Further, the same study reported $100 \%$ protection of NHP when AD5-IFN $\alpha$ was administered single time together with the first ZMAb injected $72 \mathrm{~h}$ post infection [241]. Compassionate use of $\mathrm{ZMAb}$ along with other treatments such as $\mathrm{CP}$ and favipiravir has resulted in $100 \%$ survival in 6 EVD patients [234]. Interestingly, a combination of CP and ZMAb in EVD patients resulted in a synergistic effect [242].

ZMapp, an antibody cocktail, is product of collaboration between US Mapp Biopharmaceutical, Inc. and Defyrus, Inc., This cocktail consists of the best mAb (13C6, 2G4 and 4G7) amongst the individual monoclonal antibodies which are present in Mab-003 and ZMAb [227,232]. When used to treat EBOV infected NHP, a 100\% efficacy was demonstrated, even when used $120 \mathrm{~h}$ post infection [227] 
(Table 2). Compassionate use along with other treatments resulted in saving life of two US healthcare workers [243]. Additionally, during 2014-2016 outbreak, 25 patients received ZMAb or ZMapp as compassionate drugs along with other treatments where $88 \%$ patients survived [244]. ZMapp completed phase I clinical trial (CT: NCT02363322) in 2019 and is currently a part of phase II/III clinical trial (CT: NCT03719586).

MIL77E is a mAb cocktail consisting of two Chinese hamster ovary-optimized ZMapp antibodies (13C6 and 2G4; optimized versions named MIL773 and MIL771 respectively) [228]. It demonstrated a $100 \%$ protection in infected NHP when administered $72 \mathrm{~h}$ post infection [228] (Table 2).

Autophagy seems to play a significant role in EBOV infection [23] and can be one of therapeutic targets. Several microRNAs identified in the black flying fox (natural reservoir for EBOV) were suggested to target autophagy controlling genes [245]. Autophagy induction by type-I IFN signaling pathways was suggested as the mechanism behind protection of NHP against lethal EBOV infection upon administration of eVLP consisting viral proteins [246]. A recent study advocated a critical role of autophagy associated proteins such as microtubule-associated protein 1A/B light chain 3B (LC3B) in EBOV uptake [247]. Further studies are needed to contemplate the development of therapeutic measures targeting such proteins.

Overall, various therapeutic interventions present their specific advantages (reviewed in [244]). Griffithsin exhibits desirable host toxicity profile and has a synergistic effect with other antiviral drugs [215]. Favipiravir is readily available and can be orally administered [244]. TKM-100802 presents with low manufacturing costs and requirements [244]. CP is an economic intervention which is safe, outbreak strain specific and can restore the blood volume [230,231]. ZMapp offers desirable safety and immunogenicity while MIL-77E presents a more cost-effective alternate to ZMapp [232].

Undesirable cytokine induction may present challenges during TKM-100802 treatment [244]. Efficacy of Favipiravir seems to rely on viral titers [244]. Compound 7, NSC62914, LJ001, Tolcapone, 3-deazaneplanocin A and FGI-103, FGI-104 and FGI-106 need to be tested in NHP models before a possible advancement into human trials. The major limitations of various monoclonal antibody cocktail treatment approaches are (a) high production costs (b) extensive manufacturing time (c) requirement for protocol optimization and (d) possible absence of pan-ebolavirus protection (reviewed in [232]).

\section{Open Questions}

EVD is an emerging zoonosis mainly caused by EBOV. The virus can use various routes to enter the body, while the main portal of entry remains largely unknown [17]. Studies have suggested that the virus can enter via the skin, even without cuts or abrasions [248]. Tissue-resident DCs, patrolling monocytes $\left(\mathrm{CD} 16^{+}\right.$monocytes) and inflammatory DCs were shown to contribute to virus dissemination [17,249]; however, the exact cell types, especially DC subsets, responsible for the early virus spread remain unknown [17]. Additionally, the role of DC-SIGN expressing DC in virus spread and the role of langerin expressing DC cells (resistant to EBOV infection) in adaptive immunity requires further investigation $[17,250]$. Identification of the target cell and initial steps of virus replication are essential for development of an effective therapeutics and vaccines.

EBOV infection significantly dysregulates the immune system where it could induce an immune suppression (apoptosis, immune evasion mechanisms, lymphopenia etc.) $[67,69]$ as well as activation (T cell activation, inflammation) $[58,62,66]$. The leukocyte apoptosis mechanism [23] as well as role of proliferated T cell populations during the EBOV infection [17] are yet to be clarified. Additionally, it remains unknown whether a polyfunctional $\mathrm{T}$ cell response could result in protective immunity or worsens the disease manifestation [28]. Additionally, virus persistence in immune privileged sites even after a complete recovery has been reported to cause reoccurrence of EVD [251], by unknown mechanism [17].

Activation of TLR and IFN-I pathways can induce the autophagy protecting against infection [246]. Additionally, simulation of two-pore channels (TPCs) by utilizing nicotinic acid adenine dinucleotide phosphate (NADDP) induces autophagy and helps the viral spread [252]. Hence, role of autophagy, 
involved proteins such as Rab 7 [252] and autophagy antagonists such as tetrandrine, rapamycin etc., in host response and as plausible therapeutic targets needs to be analyzed [23].

Interestingly, studies suggest that rodents, some reptiles and fruit bats are naturally immune to EBOV infection $[17,253]$. One of the reasons for their EBOV resistance is the NPC1 polymorphism, a protein essential for the virus entry [254]. Another plausible reason is the identification of several microRNA involved in upregulation of damage response and autophagy genes in response to disease inducing activities of the virus in Pteropus alecto [245]. Still, the reasons behind the high susceptibility of humans to EBOV as compared to other species require further investigation [17].

\section{Conclusions}

In conclusion, studies have demonstrated a central role of innate and adaptive immune responses during EVD. Survivor cases are marked by an early but controlled cytokine production, early T-cell activation, a recovery from a bystander T-cell apoptosis, intact CD3 T-cell population and increased serum levels of RANTES, CD40L and CD28 transcripts along with development of anti-EBOV antibodies. It appears that significant and polyclonal T-cell as well as humoral immune responses are indispensable for survival. Some viral proteins help to evade the host immune responses by displaying antigenic subversion, steric occlusion, anti-tetherin activity, shielding viral genome for RIG-I and MDA-5 and/or restricting type I and II IFN response via interference with JAK-STAT and MAPK pathways. Therapeutic and vaccine development approaches targeting different viral proteins and/or pathogenic mechanisms have demonstrated fruitful results in animal studies as well as in clinical trials. Still there is no single drug has been identified to have a cross-reactive, globally protective and easily accessible measure against EBOV.

Author Contributions: S.J., writing the major sections of review; S.F.K., review-editing, conceptualized the immunological perspective section; M.B., originated the idea of review, overall supervision, review-writing and editing. All authors have read and agreed to the published version of the manuscript.

Funding: This research received no external funding.

Acknowledgments: S.F.K. was supported by kazan federal University program of competitive growth.

Conflicts of Interest: The authors declare no conflict of interest

\section{References}

1. Ascenzi, P.; Bocedi, A.; Heptonstall, J.; Capobianchi, M.R.; Di Caro, A.; Mastrangelo, E.; Bolognesi, M.; Ippolito, G. Ebolavirus and Marburgvirus: Insight the Filoviridae family. Mol. Asp. Med. 2008, 29, 151-185. [CrossRef]

2. Jacob, S.T.; Crozier, I.; Fischer, W.A., 2nd; Hewlett, A.; Kraft, C.S.; Vega, M.A.; Soka, M.J.; Wahl, V.; Griffiths, A.; Bollinger, L.; et al. Ebola virus disease. Nat. Rev. Dis. Primers 2020, 6, 13. [CrossRef] [PubMed]

3. Kuhn, J.H. Guide to the Correct Use of Filoviral Nomenclature. Curr. Top. Microbiol. Immunol. 2017, 411, 447-460. [CrossRef] [PubMed]

4. Coltart, C.E.; Lindsey, B.; Ghinai, I.; Johnson, A.M.; Heymann, D.L. The Ebola outbreak, 2013-2016: Old lessons for new epidemics. Philos. Trans. R. Soc. Lond. Ser. B Biol. Sci. 2017, 372. [CrossRef] [PubMed]

5. Cantoni, D.; Hamlet, A.; Michaelis, M.; Wass, M.N.; Rossman, J.S. Risks Posed by Reston, the Forgotten Ebolavirus. mSphere 2016, 1. [CrossRef] [PubMed]

6. Forbes, K.M.; Webala, P.W.; Jääskeläinen, A.J.; Abdurahman, S.; Ogola, J.; Masika, M.M.; Kivistö, I.; Alburkat, H.; Plyusnin, I.; Levanov, L.; et al. Bombali Virus in Mops condylurus Bat, Kenya. Emerg. Infect. Dis. 2019, 25, 955-957. [CrossRef]

7. CDC. Available online: https://www.cdc.gov/vhf/ebola/about.html (accessed on 12 August 2020).

8. Feldmann, H.; Sprecher, A.; Geisbert, T.W. Ebola. N. Engl. J. Med. 2020, 382, 1832-1842. [CrossRef]

9. Emanuel, J.; Marzi, A.; Feldmann, H. Filoviruses: Ecology, Molecular Biology, and Evolution. Adv. Virus Res. 2018, 100, 189-221. [CrossRef] [PubMed]

10. Legrand, J.; Grais, R.F.; Boelle, P.Y.; Valleron, A.J.; Flahault, A. Understanding the dynamics of Ebola epidemics. Epidemiol. Infect. 2006, 135, 610-621. [CrossRef] [PubMed] 
11. Kamdar, M.R.; Dumontier, M. An Ebola virus-centered knowledge base. Database J. Biol. Databases Curation 2015, 2015, bav049. [CrossRef] [PubMed]

12. Madariaga, M.G. Ebola Virus Disease: A Perspective for the United States. Am. J. Med. 2015, 128, 682-691. [CrossRef]

13. Cenciarelli, O.; Gabbarini, V.; Pietropaoli, S.; Malizia, A.; Tamburrini, A.; Ludovici, G.M.; Carestia, M.; Di Giovanni, D.; Sassolini, A.; Palombi, L.; et al. Viral bioterrorism: Learning the lesson of Ebola virus in West Africa 2013-2015. Virus Res. 2015, 210, 318-326. [CrossRef]

14. Goeijenbier, M.; van Kampen, J.J.; Reusken, C.B.; Koopmans, M.P.; van Gorp, E.C. Ebola virus disease: A review on epidemiology, symptoms, treatment and pathogenesis. Neth. J. Med. 2014, 72, 442-448.

15. Marcinkiewicz, J.; Bryniarski, K.; Nazimek, K. Ebola haemorrhagic fever virus: Pathogenesis, immune responses, potential prevention. Folia Med. Crac. 2014, 54, 39-48.

16. Perdomo-Celis, F.; Salvato, M.S.; Medina-Moreno, S.; Zapata, J.C. T-Cell Response to Viral Hemorrhagic Fevers. Vaccines 2019, 7, 11. [CrossRef] [PubMed]

17. McElroy, A.K.; Muhlberger, E.; Munoz-Fontela, C. Immune barriers of Ebola virus infection. Curr. Opin. Virol. 2018, 28, 152-160. [CrossRef]

18. Hensley, L.E.; Jones, S.M.; Feldmann, H.; Jahrling, P.B.; Geisbert, T.W. Ebola and Marburg viruses: Pathogenesis and development of countermeasures. Curr. Mol. Med. 2005, 5, 761-772. [CrossRef]

19. STATNEWS. Available online: https://www.statnews.com/2017/12/08/ebola-vaccine-development/ (accessed on 7 May 2020).

20. Pharmaintelligence. Available online: https://pharmaintelligence.informa.com/resources/product-content/ missing-in-action-chinas-best-shot-in-ebola-vaccine-race (accessed on 7 May 2020).

21. EMA. Available online: https://www.ema.europa.eu/en/news/first-vaccine-protect-against-ebola (accessed on 7 May 2020).

22. FDA. Available online: https://www.fda.gov/news-events/press-announcements/first-fda-approved-vaccineprevention-ebola-virus-disease-marking-critical-milestone-public-health (accessed on 7 May 2020).

23. Falasca, L.; Agrati, C.; Petrosillo, N.; Di Caro, A.; Capobianchi, M.R.; Ippolito, G.; Piacentini, M. Molecular mechanisms of Ebola virus pathogenesis: Focus on cell death. Cell Death Differ. 2015, 22, 1250-1259. [CrossRef] [PubMed]

24. Olejnik, J.; Ryabchikova, E.; Corley, R.B.; Mühlberger, E. Intracellular events and cell fate in filovirus infection. Viruses 2011, 3, 1501-1531. [CrossRef] [PubMed]

25. Schnittler, H.J.; Feldmann, H. Marburg and Ebola hemorrhagic fevers: Does the primary course of infection depend on the accessibility of organ-specific macrophages? Clin. Infect. Dis. Off. Publ. Infect. Dis. Soc. Am. 1998, 27, 404-406. [CrossRef]

26. Geisbert, T.W.; Hensley, L.E.; Larsen, T.; Young, H.A.; Reed, D.S.; Geisbert, J.B.; Scott, D.P.; Kagan, E.; Jahrling, P.B.; Davis, K.J. Pathogenesis of Ebola hemorrhagic fever in cynomolgus macaques: Evidence that dendritic cells are early and sustained targets of infection. Am. J. Pathol. 2003, 163, 2347-2370. [CrossRef]

27. Bray, M.; Geisbert, T.W. Ebola virus: The role of macrophages and dendritic cells in the pathogenesis of Ebola hemorrhagic fever. Int. J. Biochem. Cell Biol. 2005, 37, 1560-1566. [CrossRef] [PubMed]

28. Munoz-Fontela, C.; McElroy, A.K. Ebola Virus Disease in Humans: Pathophysiology and Immunity. Curr. Top. Microbiol. Immunol. 2017, 411, 141-169. [CrossRef]

29. Saeed, M.F.; Kolokoltsov, A.A.; Albrecht, T.; Davey, R.A. Cellular entry of ebola virus involves uptake by a macropinocytosis-like mechanism and subsequent trafficking through early and late endosomes. PLoS Pathog. 2010, 6, e1001110. [CrossRef] [PubMed]

30. Bavari, S.; Bosio, C.M.; Wiegand, E.; Ruthel, G.; Will, A.B.; Geisbert, T.W.; Hevey, M.; Schmaljohn, C.; Schmaljohn, A.; Aman, M.J. Lipid raft microdomains: A gateway for compartmentalized trafficking of Ebola and Marburg viruses. J. Exp. Med. 2002, 195, 593-602. [CrossRef] [PubMed]

31. Marzi, A.; Gramberg, T.; Simmons, G.; Möller, P.; Rennekamp, A.J.; Krumbiegel, M.; Geier, M.; Eisemann, J.; Turza, N.; Saunier, B.; et al. DC-SIGN and DC-SIGNR interact with the glycoprotein of Marburg virus and the $S$ protein of severe acute respiratory syndrome coronavirus. J. Virol. 2004, 78, 12090-12095. [CrossRef]

32. Takada, A.; Watanabe, S.; Ito, H.; Okazaki, K.; Kida, H.; Kawaoka, Y. Downregulation of beta1 integrins by Ebola virus glycoprotein: Implication for virus entry. Virology 2000, 278, 20-26. [CrossRef] [PubMed] 
33. Takada, A.; Fujioka, K.; Tsuiji, M.; Morikawa, A.; Higashi, N.; Ebihara, H.; Kobasa, D.; Feldmann, H.; Irimura, T.; Kawaoka, Y. Human macrophage C-type lectin specific for galactose and $\mathrm{N}$-acetylgalactosamine promotes filovirus entry. J. Virol. 2004, 78, 2943-2947. [CrossRef]

34. Davey, R.A.; Shtanko, O.; Anantpadma, M.; Sakurai, Y.; Chandran, K.; Maury, W. Mechanisms of Filovirus Entry. Curr. Top. Microbiol. Immunol. 2017, 411, 323-352. [CrossRef]

35. Alvarez, C.P.; Lasala, F.; Carrillo, J.; Muñiz, O.; Corbí, A.L.; Delgado, R. C-type lectins DC-SIGN and L-SIGN mediate cellular entry by Ebola virus in cis and in trans. J. Virol. 2002, 76, 6841-6844. [CrossRef]

36. Yu, D.S.; Weng, T.H.; Wu, X.X.; Wang, F.X.C.; Lu, X.Y.; Wu, H.B.; Wu, N.P.; Li, L.J.; Yao, H.P. The lifecycle of the Ebola virus in host cells. Oncotarget 2017, 8, 55750-55759. [CrossRef] [PubMed]

37. White, J.M.; Schornberg, K.L. A new player in the puzzle of filovirus entry. Nat. Rev. Microbiol. 2012, 10, 317-322. [CrossRef] [PubMed]

38. Carette, J.E.; Raaben, M.; Wong, A.C.; Herbert, A.S.; Obernosterer, G.; Mulherkar, N.; Kuehne, A.I.; Kranzusch, P.J.; Griffin, A.M.; Ruthel, G.; et al. Ebola virus entry requires the cholesterol transporter Niemann-Pick C1. Nature 2011, 477, 340-343. [CrossRef] [PubMed]

39. Bär, S.; Takada, A.; Kawaoka, Y.; Alizon, M. Detection of cell-cell fusion mediated by Ebola virus glycoproteins. J. Virol. 2006, 80, 2815-2822. [CrossRef] [PubMed]

40. Simpson, J.C.; Joggerst, B.; Laketa, V.; Verissimo, F.; Cetin, C.; Erfle, H.; Bexiga, M.G.; Singan, V.R.; Hériché, J.K.; Neumann, B.; et al. Genome-wide RNAi screening identifies human proteins with a regulatory function in the early secretory pathway. Nat. Cell Biol. 2012, 14, 764-774. [CrossRef]

41. Schornberg, K.; Matsuyama, S.; Kabsch, K.; Delos, S.; Bouton, A.; White, J. Role of endosomal cathepsins in entry mediated by the Ebola virus glycoprotein. J. Virol. 2006, 80, 4174-4178. [CrossRef]

42. Malashkevich, V.N.; Schneider, B.J.; McNally, M.L.; Milhollen, M.A.; Pang, J.X.; Kim, P.S. Core structure of the envelope glycoprotein GP2 from Ebola virus at 1.9-A resolution. Proc. Natl. Acad. Sci. USA 1999, 96, 2662-2667. [CrossRef]

43. Geisbert, T.W.; Hensley, L.E. Ebola virus: New insights into disease aetiopathology and possible therapeutic interventions. Expert Rev. Mol. Med. 2004, 6, 1-24. [CrossRef]

44. Safari, S.; Baratloo, A.; Rouhipour, A.; Ghelichkhani, P.; Yousefifard, M. Ebola Hemorrhagic Fever as a Public Health Emergency of International Concern; a Review Article. Emergency (Tehraniran) 2015, 3, 3-7.

45. Heller, J.A.; DeMaria, S.; Levine, A.; Heller, B.J.; Augoustides, J.G.; Stone, M.; Silvay, G.; Goldberg, A. Cardiovascular and Pulmonary Impact of the Ebola Virus: A Review of Current Literature and Practices. J. Cardiothorac. Vasc. Anesth. 2015, 29, 1672-1676. [CrossRef]

46. Hunt, L.; Gupta-Wright, A.; Simms, V.; Tamba, F.; Knott, V.; Tamba, K.; Heisenberg-Mansaray, S.; Tamba, E.; Sheriff, A.; Conteh, S.; et al. Clinical presentation, biochemical, and haematological parameters and their association with outcome in patients with Ebola virus disease: An observational cohort study. Lancet Infect. Dis. 2015, 15, 1292-1299. [CrossRef]

47. Uyeki, T.M.; Mehta, A.K.; Davey, R.T., Jr.; Liddell, A.M.; Wolf, T.; Vetter, P.; Schmiedel, S.; Grunewald, T.; Jacobs, M.; Arribas, J.R.; et al. Clinical Management of Ebola Virus Disease in the United States and Europe. N. Engl. J. Med. 2016, 374, 636-646. [CrossRef]

48. Kindrachuk, J.; Wahl-Jensen, V.; Safronetz, D.; Trost, B.; Hoenen, T.; Arsenault, R.; Feldmann, F.; Traynor, D.; Postnikova, E.; Kusalik, A.; et al. Ebola virus modulates transforming growth factor $\beta$ signaling and cellular markers of mesenchyme-like transition in hepatocytes. J. Virol. 2014, 88, 9877-9892. [CrossRef] [PubMed]

49. Paessler, S.; Walker, D.H. Pathogenesis of the viral hemorrhagic fevers. Annu. Rev. Pathol. 2013, 8, 411-440. [CrossRef]

50. McElroy, A.K.; Erickson, B.R.; Flietstra, T.D.; Rollin, P.E.; Nichol, S.T.; Towner, J.S.; Spiropoulou, C.F. Ebola hemorrhagic Fever: Novel biomarker correlates of clinical outcome. J. Infect. Dis. 2014, 210, 558-566. [CrossRef] [PubMed]

51. Lalle, E.; Biava, M.; Nicastri, E.; Colavita, F.; Di Caro, A.; Vairo, F.; Lanini, S.; Castilletti, C.; Langer, M.; Zumla, A.; et al. Pulmonary Involvement during the Ebola Virus Disease. Viruses 2019, 11, 780. [CrossRef]

52. Billioux, B.J.; Smith, B.; Nath, A. Neurological Complications of Ebola Virus Infection. Neurother. J. Am. Soc. Exp. Neurother. 2016, 13, 461-470. [CrossRef] [PubMed]

53. Shantha, J.G.; Crozier, I.; Yeh, S. An update on ocular complications of Ebola virus disease. Curr. Opin. Ophthalmol. 2017, 28, 600-606. [CrossRef] 
54. Wong, K.K.; Perdue, C.L.; Malia, J.; Kenney, J.L.; Peng, S.; Gwathney, J.K.; Raczniak, G.A. Supportive Care of the First 2 Ebola Virus Disease Patients at the Monrovia Medical Unit. Clin. Infect. Dis. Off. Publ. Infect. Dis. Soc. Am. 2015, 61, e47-e51. [CrossRef]

55. Amissah-Arthur, M.B.; Poller, B.; Tunbridge, A.; Adebajo, A. Musculoskeletal manifestations of Ebola virus. Rheumatology 2018, 57, 28-31. [CrossRef]

56. McElroy, A.K.; Akondy, R.S.; Davis, C.W.; Ellebedy, A.H.; Mehta, A.K.; Kraft, C.S.; Lyon, G.M.; Ribner, B.S.; Varkey, J.; Sidney, J.; et al. Human Ebola virus infection results in substantial immune activation. Proc. Natl. Acad. Sci. USA 2015, 112, 4719-4724. [CrossRef] [PubMed]

57. Mahanty, S.; Hutchinson, K.; Agarwal, S.; McRae, M.; Rollin, P.E.; Pulendran, B. Cutting edge: Impairment of dendritic cells and adaptive immunity by Ebola and Lassa viruses. J. Immunol. 2003, 170, 2797-2801. [CrossRef] [PubMed]

58. Ruibal, P.; Oestereich, L.; Ludtke, A.; Becker-Ziaja, B.; Wozniak, D.M.; Kerber, R.; Korva, M.; Cabeza-Cabrerizo, M.; Bore, J.A.; Koundouno, F.R.; et al. Unique human immune signature of Ebola virus disease in Guinea. Nature 2016, 533, 100-104. [CrossRef]

59. Sullivan, N.J.; Hensley, L.; Asiedu, C.; Geisbert, T.W.; Stanley, D.; Johnson, J.; Honko, A.; Olinger, G.; Bailey, M.; Geisbert, J.B.; et al. CD8+ cellular immunity mediates rAd5 vaccine protection against Ebola virus infection of nonhuman primates. Nat. Med. 2011, 17, 1128-1131. [CrossRef] [PubMed]

60. Marzi, A.; Engelmann, F.; Feldmann, F.; Haberthur, K.; Shupert, W.L.; Brining, D.; Scott, D.P.; Geisbert, T.W.; Kawaoka, Y.; Katze, M.G.; et al. Antibodies are necessary for rVSV/ZEBOV-GP-mediated protection against lethal Ebola virus challenge in nonhuman primates. Proc. Natl. Acad. Sci. USA 2013, 110, 1893-1898. [CrossRef]

61. Sakabe, S.; Sullivan, B.M.; Hartnett, J.N.; Robles-Sikisaka, R.; Gangavarapu, K.; Cubitt, B.; Ware, B.C.; Kotliar, D.; Branco, L.M.; Goba, A.; et al. Analysis of CD8(+) T cell response during the 2013-2016 Ebola epidemic in West Africa. Proc. Natl. Acad. Sci. USA 2018, 115, E7578-E7586. [CrossRef]

62. Speranza, E.; Ruibal, P.; Port, J.R.; Feng, F.; Burkhardt, L.; Grundhoff, A.; Günther, S.; Oestereich, L.; Hiscox, J.A.; Connor, J.H.; et al. T-Cell Receptor Diversity and the Control of T-Cell Homeostasis Mark Ebola Virus Disease Survival in Humans. J. Infect. Dis. 2018, 218, S508-S518. [CrossRef]

63. Wherry, E.J. T cell exhaustion. Nat. Immunol. 2011, 12, 492-499. [CrossRef]

64. Mohamadzadeh, M.; Chen, L.; Schmaljohn, A.L. How Ebola and Marburg viruses battle the immune system. Nat. Rev. Immunol. 2007, 7, 556-567. [CrossRef]

65. Kaufmann, D.E.; Kavanagh, D.G.; Pereyra, F.; Zaunders, J.J.; Mackey, E.W.; Miura, T.; Palmer, S.; Brockman, M.; Rathod, A.; Piechocka-Trocha, A.; et al. Upregulation of CTLA-4 by HIV-specific CD4+ T cells correlates with disease progression and defines a reversible immune dysfunction. Nat. Immunol. 2007, 8, 1246-1254. [CrossRef]

66. Dahlke, C.; Lunemann, S.; Kasonta, R.; Kreuels, B.; Schmiedel, S.; Ly, M.L.; Fehling, S.K.; Strecker, T.; Becker, S.; Altfeld, M.; et al. Comprehensive Characterization of Cellular Immune Responses Following Ebola Virus Infection. J. Infect. Dis. 2017, 215, 287-292. [CrossRef] [PubMed]

67. Iampietro, M.; Younan, P.; Nishida, A.; Dutta, M.; Lubaki, N.M.; Santos, R.I.; Koup, R.A.; Katze, M.G.; Bukreyev, A. Ebola virus glycoprotein directly triggers T lymphocyte death despite of the lack of infection. PLoS Pathog. 2017, 13, e1006397. [CrossRef]

68. Reed, D.S.; Hensley, L.E.; Geisbert, J.B.; Jahrling, P.B.; Geisbert, T.W. Depletion of peripheral blood T lymphocytes and NK cells during the course of ebola hemorrhagic Fever in cynomolgus macaques. Viral Immunol. 2004, 17, 390-400. [CrossRef] [PubMed]

69. Agrati, C.; Castilletti, C.; Casetti, R.; Sacchi, A.; Falasca, L.; Turchi, F.; Tumino, N.; Bordoni, V.; Cimini, E.; Viola, D.; et al. Longitudinal characterization of dysfunctional T cell-activation during human acute Ebola infection. Cell Death Dis. 2016, 7, e2164. [CrossRef] [PubMed]

70. Baize, S.; Leroy, E.M.; Georges-Courbot, M.C.; Capron, M.; Lansoud-Soukate, J.; Debré, P.; Fisher-Hoch, S.P.; McCormick, J.B.; Georges, A.J. Defective humoral responses and extensive intravascular apoptosis are associated with fatal outcome in Ebola virus-infected patients. Nat. Med. 1999, 5, 423-426. [CrossRef]

71. Rojas, M.; Monsalve, D.M.; Pacheco, Y.; Acosta-Ampudia, Y.; Ramírez-Santana, C.; Ansari, A.A.; Gershwin, M.E.; Anaya, J.M. Ebola virus disease: An emerging and re-emerging viral threat. J. Autoimmun. 2020, 106, 102375. [CrossRef] 
72. Basler, C.F.; Palese, P. Molecular and Cellular Biology. In Ebola and Marburg Viruses; Horizon Bioscience: Norfolk, UK, 2004; pp. 305-349.

73. Bradfute, S.B.; Warfield, K.L.; Bavari, S. Functional CD8+ T cell responses in lethal Ebola virus infection. J. Immunol. 2008, 180, 4058-4066. [CrossRef] [PubMed]

74. Gupta, M.; Mahanty, S.; Greer, P.; Towner, J.S.; Shieh, W.J.; Zaki, S.R.; Ahmed, R.; Rollin, P.E. Persistent infection with ebola virus under conditions of partial immunity. J. Virol. 2004, 78, 958-967. [CrossRef]

75. Ströher, U.; West, E.; Bugany, H.; Klenk, H.D.; Schnittler, H.J.; Feldmann, H. Infection and activation of monocytes by Marburg and Ebola viruses. J. Virol. 2001, 75, 11025-11033. [CrossRef]

76. Geisbert, T.W.; Young, H.A.; Jahrling, P.B.; Davis, K.J.; Kagan, E.; Hensley, L.E. Mechanisms underlying coagulation abnormalities in ebola hemorrhagic fever: Overexpression of tissue factor in primate monocytes/macrophages is a key event. J. Infect. Dis. 2003, 188, 1618-1629. [CrossRef]

77. Hensley, L.E.; Young, H.A.; Jahrling, P.B.; Geisbert, T.W. Proinflammatory response during Ebola virus infection of primate models: Possible involvement of the tumor necrosis factor receptor superfamily. Immunol. Lett. 2002, 80, 169-179. [CrossRef]

78. Gupta, M.; Mahanty, S.; Ahmed, R.; Rollin, P.E. Monocyte-derived human macrophages and peripheral blood mononuclear cells infected with ebola virus secrete MIP-1alpha and TNF-alpha and inhibit poly-IC-induced IFN-alpha in vitro. Virology 2001, 284, 20-25. [CrossRef]

79. Younan, P.; Iampietro, M.; Nishida, A.; Ramanathan, P.; Santos, R.I.; Dutta, M.; Lubaki, N.M.; Koup, R.A.; Katze, M.G.; Bukreyev, A. Ebola Virus Binding to Tim-1 on T Lymphocytes Induces a Cytokine Storm. mBio 2017, 8. [CrossRef] [PubMed]

80. Melanson, V.R.; Kalina, W.V.; Williams, P. Ebola virus infection induces irregular dendritic cell gene expression. Viral Immunol. 2015, 28, 42-50. [CrossRef]

81. Wahl-Jensen, V.; Kurz, S.; Feldmann, F.; Buehler, L.K.; Kindrachuk, J.; DeFilippis, V.; da Silva Correia, J.; Früh, K.; Kuhn, J.H.; Burton, D.R.; et al. Ebola virion attachment and entry into human macrophages profoundly effects early cellular gene expression. PLoS Negl. Trop. Dis. 2011, 5, e1359. [CrossRef]

82. Escudero-Perez, B.; Volchkova, V.A.; Dolnik, O.; Lawrence, P.; Volchkov, V.E. Shed GP of Ebola virus triggers immune activation and increased vascular permeability. PLoS Pathog. 2014, 10, e1004509. [CrossRef]

83. Wauquier, N.; Becquart, P.; Padilla, C.; Baize, S.; Leroy, E.M. Human fatal zaire ebola virus infection is associated with an aberrant innate immunity and with massive lymphocyte apoptosis. PLoS Negl. Trop. Dis. 2010, 4. [CrossRef] [PubMed]

84. McElroy, A.K.; Harmon, J.R.; Flietstra, T.D.; Campbell, S.; Mehta, A.K.; Kraft, C.S.; Lyon, M.G.; Varkey, J.B.; Ribner, B.S.; Kratochvil, C.J.; et al. Kinetic Analysis of Biomarkers in a Cohort of US Patients with Ebola Virus Disease. Clin. Infect. Dis. Off. Publ. Infect. Dis. Soc. Am. 2016, 63, 460-467. [CrossRef]

85. Villinger, F.; Rollin, P.E.; Brar, S.S.; Chikkala, N.F.; Winter, J.; Sundstrom, J.B.; Zaki, S.R.; Swanepoel, R.; Ansari, A.A.; Peters, C.J. Markedly elevated levels of interferon (IFN)-gamma, IFN-alpha, interleukin (IL)-2, IL-10, and tumor necrosis factor-alpha associated with fatal Ebola virus infection. J. Infect. Dis. 1999, 179 (Suppl. 1), S188-S191. [CrossRef]

86. Baize, S.; Leroy, E.M.; Georges, A.J.; Georges-Courbot, M.C.; Capron, M.; Bedjabaga, I.; Lansoud-Soukate, J.; Mavoungou, E. Inflammatory responses in Ebola virus-infected patients. Clin. Exp. Immunol. 2002, 128, 163-168. [CrossRef]

87. Sanchez, A.; Lukwiya, M.; Bausch, D.; Mahanty, S.; Sanchez, A.J.; Wagoner, K.D.; Rollin, P.E. Analysis of human peripheral blood samples from fatal and nonfatal cases of Ebola (Sudan) hemorrhagic fever: Cellular responses, virus load, and nitric oxide levels. J. Virol. 2004, 78, 10370-10377. [CrossRef]

88. Hutchinson, K.L.; Rollin, P.E. Cytokine and chemokine expression in humans infected with Sudan Ebola virus. J. Infect. Dis. 2007, 196 (Suppl. 2), S357-S363. [CrossRef] [PubMed]

89. Neumann, F.J.; Ott, I.; Marx, N.; Luther, T.; Kenngott, S.; Gawaz, M.; Kotzsch, M.; Schömig, A. Effect of human recombinant interleukin-6 and interleukin-8 on monocyte procoagulant activity. Arterioscler. Thromb. Vasc. Biol. 1997, 17, 3399-3405. [CrossRef]

90. Lee, M.E.; Rhee, K.J.; Nham, S.U. Fragment E derived from both fibrin and fibrinogen stimulates interleukin-6 production in rat peritoneal macrophages. Mol. Cells 1999, 9, 7-13.

91. Yang, Z.Y.; Duckers, H.J.; Sullivan, N.J.; Sanchez, A.; Nabel, E.G.; Nabel, G.J. Identification of the Ebola virus glycoprotein as the main viral determinant of vascular cell cytotoxicity and injury. Nat. Med. 2000, 6, 886-889. [CrossRef] 
92. Ray, R.B.; Basu, A.; Steele, R.; Beyene, A.; McHowat, J.; Meyer, K.; Ghosh, A.K.; Ray, R. Ebola virus glycoprotein-mediated anoikis of primary human cardiac microvascular endothelial cells. Virology 2004, 321, 181-188. [CrossRef] [PubMed]

93. Wahl-Jensen, V.M.; Afanasieva, T.A.; Seebach, J.; Ströher, U.; Feldmann, H.; Schnittler, H.J. Effects of Ebola virus glycoproteins on endothelial cell activation and barrier function. J. Virol. 2005, 79, 10442-10450. [CrossRef] [PubMed]

94. Zaki, S.R.; Goldsmith, C.S. Pathologic features of filovirus infections in humans. Curr. Top. Microbiol. Immunol. 1999, 235, 97-116. [CrossRef]

95. Murphy, F.A. Pathology of Ebola virus infection. In Ebola Virus Haemorrhagic Fever; SR, P., Ed.; Elsevier/NorthHolland Biomedical Press: New York, NY, USA, 1978; pp. 43-60.

96. Johnson, K.M.; Lange, J.V.; Webb, P.A.; Murphy, F.A. Isolation and partial characterisation of a new virus causing acute haemorrhagic fever in Zaire. Lancet 1977, 1, 569-571. [CrossRef]

97. Feldmann, H.; Bugany, H.; Mahner, F.; Klenk, H.D.; Drenckhahn, D.; Schnittler, H.J. Filovirus-induced endothelial leakage triggered by infected monocytes/macrophages. J. Virol. 1996, 70, 2208-2214. [CrossRef]

98. Stolpen, A.H.; Guinan, E.C.; Fiers, W.; Pober, J.S. Recombinant tumor necrosis factor and immune interferon act singly and in combination to reorganize human vascular endothelial cell monolayers. Am. J. Pathol. 1986, 123, 16-24. [PubMed]

99. Brett, J.; Gerlach, H.; Nawroth, P.; Steinberg, S.; Godman, G.; Stern, D. Tumor necrosis factor/cachectin increases permeability of endothelial cell monolayers by a mechanism involving regulatory $\mathrm{G}$ proteins. J. Exp. Med. 1989, 169, 1977-1991. [CrossRef] [PubMed]

100. Towner, J.S.; Rollin, P.E.; Bausch, D.G.; Sanchez, A.; Crary, S.M.; Vincent, M.; Lee, W.F.; Spiropoulou, C.F.; Ksiazek, T.G.; Lukwiya, M.; et al. Rapid diagnosis of Ebola hemorrhagic fever by reverse transcription-PCR in an outbreak setting and assessment of patient viral load as a predictor of outcome. J. Virol. 2004, 78, 4330-4341. [CrossRef]

101. Luczkowiak, J.; Arribas, J.R.; Gómez, S.; Jiménez-Yuste, V.; de la Calle, F.; Viejo, A.; Delgado, R. Specific neutralizing response in plasma from convalescent patients of Ebola Virus Disease against the West Africa Makona variant of Ebola virus. Virus Res. 2016, 213, 224-229. [CrossRef]

102. Sobarzo, A.; Perelman, E.; Groseth, A.; Dolnik, O.; Becker, S.; Lutwama, J.J.; Dye, J.M.; Yavelsky, V.; Lobel, L.; Marks, R.S. Profiling the native specific human humoral immune response to Sudan Ebola virus strain Gulu by chemiluminescence enzyme-linked immunosorbent assay. Clin. Vaccine Immunol. 2012, 19, 1844-1852. [CrossRef] [PubMed]

103. Onyango, C.O.; Opoka, M.L.; Ksiazek, T.G.; Formenty, P.; Ahmed, A.; Tukei, P.M.; Sang, R.C.; Ofula, V.O.; Konongoi, S.L.; Coldren, R.L.; et al. Laboratory diagnosis of Ebola hemorrhagic fever during an outbreak in Yambio, Sudan, 2004. J. Infect. Dis. 2007, 196 (Suppl. 2), S193-S198. [CrossRef] [PubMed]

104. Olejnik, J.; Hume, A.J.; Leung, D.W.; Amarasinghe, G.K.; Basler, C.F.; Muhlberger, E. Filovirus Strategies to Escape Antiviral Responses. Curr. Top. Microbiol. Immunol. 2017, 411, 293-322. [CrossRef]

105. Audet, J.; Kobinger, G.P. Immune evasion in ebolavirus infections. Viral Immunol. 2015, 28, 10-18. [CrossRef]

106. Xu, W.; Edwards, M.R.; Borek, D.M.; Feagins, A.R.; Mittal, A.; Alinger, J.B.; Berry, K.N.; Yen, B.; Hamilton, J.; Brett, T.J.; et al. Ebola virus VP24 targets a unique NLS binding site on karyopherin alpha 5 to selectively compete with nuclear import of phosphorylated STAT1. Cell Host Microbe 2014, 16, 187-200. [CrossRef]

107. Shabman, R.S.; Gulcicek, E.E.; Stone, K.L.; Basler, C.F. The Ebola virus VP24 protein prevents hnRNP C1/C2 binding to karyopherin $\alpha 1$ and partially alters its nuclear import. J. Infect. Dis. 2011, 204 (Suppl. 3), S904-S910. [CrossRef]

108. Basler, C.F. Innate immune evasion by filoviruses. Virology 2015, 479-480, 122-130. [CrossRef] [PubMed]

109. Guito, J.C.; Albariño, C.G.; Chakrabarti, A.K.; Towner, J.S. Novel activities by ebolavirus and marburgvirus interferon antagonists revealed using a standardized in vitro reporter system. Virology 2017, 501, 147-165. [CrossRef]

110. Halfmann, P.; Neumann, G.; Kawaoka, Y. The Ebolavirus VP24 protein blocks phosphorylation of p38 mitogen-activated protein kinase. J. Infect. Dis. 2011, 204 (Suppl. 3), S953-S956. [CrossRef]

111. Prins, K.C.; Delpeut, S.; Leung, D.W.; Reynard, O.; Volchkova, V.A.; Reid, S.P.; Ramanan, P.; Cárdenas, W.B.; Amarasinghe, G.K.; Volchkov, V.E.; et al. Mutations abrogating VP35 interaction with double-stranded RNA render Ebola virus avirulent in guinea pigs. J. Virol. 2010, 84, 3004-3015. [CrossRef] [PubMed] 
112. Leung, D.W.; Prins, K.C.; Borek, D.M.; Farahbakhsh, M.; Tufariello, J.M.; Ramanan, P.; Nix, J.C.; Helgeson, L.A.; Otwinowski, Z.; Honzatko, R.B.; et al. Structural basis for dsRNA recognition and interferon antagonism by Ebola VP35. Nat. Struct. Mol. Biol. 2010, 17, 165-172. [CrossRef] [PubMed]

113. Luthra, P.; Ramanan, P.; Mire, C.E.; Weisend, C.; Tsuda, Y.; Yen, B.; Liu, G.; Leung, D.W.; Geisbert, T.W.; Ebihara, H.; et al. Mutual Antagonism between the Ebola Virus VP35 Protein and the RIG-I Activator PACT Determines Infection Outcome. Cell Host Microbe 2013, 14, 74-84. [CrossRef]

114. Prins, K.C.; Binning, J.M.; Shabman, R.S.; Leung, D.W.; Amarasinghe, G.K.; Basler, C.F. Basic residues within the ebolavirus VP35 protein are required for its viral polymerase cofactor function. J. Virol. 2010, 84, 10581-10591. [CrossRef]

115. García, M.A.; Meurs, E.F.; Esteban, M. The dsRNA protein kinase PKR: Virus and cell control. Biochimie 2007, 89, 799-811. [CrossRef]

116. Schümann, M.; Gantke, T.; Mühlberger, E. Ebola virus VP35 antagonizes PKR activity through its C-terminal interferon inhibitory domain. J. Virol. 2009, 83, 8993-8997. [CrossRef]

117. Prins, K.C.; Cárdenas, W.B.; Basler, C.F. Ebola virus protein VP35 impairs the function of interferon regulatory factor-activating kinases IKKepsilon and TBK-1. J. Virol. 2009, 83, 3069-3077. [CrossRef]

118. Chang, T.-H.; Kubota, T.; Matsuoka, M.; Jones, S.; Bradfute, S.B.; Bray, M.; Ozato, K. Ebola Zaire virus blocks type I interferon production by exploiting the host SUMO modification machinery. PLoS Pathog. 2009, 5, e1000493. [CrossRef] [PubMed]

119. Basler, C.F.; Amarasinghe, G.K. Evasion of interferon responses by Ebola and Marburg viruses. J. Interferon Cytokine Res. Off. J. Int. Soc. Interferon Cytokine Res. 2009, 29, 511-520. [CrossRef] [PubMed]

120. Basler, C.F.; Mikulasova, A.; Martinez-Sobrido, L.; Paragas, J.; Mühlberger, E.; Bray, M.; Klenk, H.D.; Palese, P.; García-Sastre, A. The Ebola virus VP35 protein inhibits activation of interferon regulatory factor 3. J. Virol. 2003, 77, 7945-7956. [CrossRef]

121. Lubaki, N.M.; Ilinykh, P.; Pietzsch, C.; Tigabu, B.; Freiberg, A.N.; Koup, R.A.; Bukreyev, A. The Lack of Maturation of Ebola Virus-Infected Dendritic Cells Results from the Cooperative Effect of at Least Two Viral Domains. J. Virol. 2013, 87, 7471. [CrossRef]

122. Mohan, G.S.; Li, W.; Ye, L.; Compans, R.W.; Yang, C. Antigenic subversion: A novel mechanism of host immune evasion by Ebola virus. PLoS Pathog. 2012, 8, e1003065. [CrossRef]

123. Collar, A.L.; Clarke, E.C.; Anaya, E.; Merrill, D.; Yarborough, S.; Anthony, S.M.; Kuhn, J.H.; Merle, C.; Theisen, M.; Bradfute, S.B. Comparison of N- and O-linked glycosylation patterns of ebolavirus glycoproteins. Virology 2017, 502, 39-47. [CrossRef]

124. Francica, J.R.; Varela-Rohena, A.; Medvec, A.; Plesa, G.; Riley, J.L.; Bates, P. Steric shielding of surface epitopes and impaired immune recognition induced by the ebola virus glycoprotein. PLoS Pathog. 2010, 6, e1001098. [CrossRef]

125. Kühl, A.; Banning, C.; Marzi, A.; Votteler, J.; Steffen, I.; Bertram, S.; Glowacka, I.; Konrad, A.; Stürzl, M.; Guo, J.T.; et al. The Ebola virus glycoprotein and HIV-1 Vpu employ different strategies to counteract the antiviral factor tetherin. J. Infect. Dis. 2011, 204 (Suppl. 3), S850-S860. [CrossRef]

126. Cocka, L.J.; Bates, P. Identification of Alternatively Translated Tetherin Isoforms with Differing Antiviral and Signaling Activities. PLoS Pathog. 2012, 8, e1002931. [CrossRef]

127. Lupton, H.W.; Lambert, R.D.; Bumgardner, D.L.; Moe, J.B.; Eddy, G.A. Inactivated vaccine for Ebola virus efficacious in guineapig model. Lancet 1980, 2, 1294-1295. [CrossRef]

128. Vanderzanden, L.; Bray, M.; Fuller, D.; Roberts, T.; Custer, D.; Spik, K.; Jahrling, P.; Huggins, J.; Schmaljohn, A.; Schmaljohn, C. DNA vaccines expressing either the GP or NP genes of Ebola virus protect mice from lethal challenge. Virology 1998, 246, 134-144. [CrossRef]

129. Herbert, A.S.; Kuehne, A.I.; Barth, J.F.; Ortiz, R.A.; Nichols, D.K.; Zak, S.E.; Stonier, S.W.; Muhammad, M.A.; Bakken, R.R.; Prugar, L.I.; et al. Venezuelan equine encephalitis virus replicon particle vaccine protects nonhuman primates from intramuscular and aerosol challenge with ebolavirus. J. Virol. 2013, 87, 4952-4964. [CrossRef]

130. Hevey, M.; Negley, D.; Pushko, P.; Smith, J.; Schmaljohn, A. Marburg virus vaccines based upon alphavirus replicons protect guinea pigs and nonhuman primates. Virology 1998, 251, 28-37. [CrossRef]

131. Pushko, P.; Bray, M.; Ludwig, G.V.; Parker, M.; Schmaljohn, A.; Sanchez, A.; Jahrling, P.B.; Smith, J.F. Recombinant RNA replicons derived from attenuated Venezuelan equine encephalitis virus protect guinea pigs and mice from Ebola hemorrhagic fever virus. Vaccine 2000, 19, 142-153. [CrossRef] 
132. Warfield, K.L.; Swenson, D.L.; Olinger, G.G.; Kalina, W.V.; Aman, M.J.; Bavari, S. Ebola virus-like particle-based vaccine protects nonhuman primates against lethal Ebola virus challenge. J. Infect. Dis. 2007, 196 (Suppl. 2), S430-S437. [CrossRef] [PubMed]

133. Geisbert, T.W.; Bailey, M.; Hensley, L.; Asiedu, C.; Geisbert, J.; Stanley, D.; Honko, A.; Johnson, J.; Mulangu, S.; Pau, M.G.; et al. Recombinant adenovirus serotype 26 (Ad26) and Ad35 vaccine vectors bypass immunity to Ad5 and protect nonhuman primates against ebolavirus challenge. J. Virol. 2011, 85, 4222-4233. [CrossRef] [PubMed]

134. Sullivan, N.J.; Sanchez, A.; Rollin, P.E.; Yang, Z.Y.; Nabel, G.J. Development of a preventive vaccine for Ebola virus infection in primates. Nature 2000, 408, 605-609. [CrossRef]

135. Swenson, D.L.; Wang, D.; Luo, M.; Warfield, K.L.; Woraratanadharm, J.; Holman, D.H.; Dong, J.Y.; Pratt, W.D. Vaccine to confer to nonhuman primates complete protection against multistrain Ebola and Marburg virus infections. Clin. Vaccine Immunol. 2008, 15, 460-467. [CrossRef]

136. Marzi, A.; Halfmann, P.; Hill-Batorski, L.; Feldmann, F.; Shupert, W.L.; Neumann, G.; Feldmann, H.; Kawaoka, Y. Vaccines. An Ebola whole-virus vaccine is protective in nonhuman primates. Science 2015, 348, 439-442. [CrossRef] [PubMed]

137. Stanley, D.A.; Honko, A.N.; Asiedu, C.; Trefry, J.C.; Lau-Kilby, A.W.; Johnson, J.C.; Hensley, L.; Ammendola, V.; Abbate, A.; Grazioli, F.; et al. Chimpanzee adenovirus vaccine generates acute and durable protective immunity against ebolavirus challenge. Nat. Med. 2014, 20, 1126-1129. [CrossRef]

138. Grant-Klein, R.J.; Altamura, L.A.; Badger, C.V.; Bounds, C.E.; Van Deusen, N.M.; Kwilas, S.A.; Vu, H.A.; Warfield, K.L.; Hooper, J.W.; Hannaman, D.; et al. Codon-optimized filovirus DNA vaccines delivered by intramuscular electroporation protect cynomolgus macaques from lethal Ebola and Marburg virus challenges. Hum. Vaccines Immunother. 2015, 11, 1991-2004. [CrossRef] [PubMed]

139. Bukreyev, A.; Marzi, A.; Feldmann, F.; Zhang, L.; Yang, L.; Ward, J.M.; Dorward, D.W.; Pickles, R.J.; Murphy, B.R.; Feldmann, H.; et al. Chimeric human parainfluenza virus bearing the Ebola virus glycoprotein as the sole surface protein is immunogenic and highly protective against Ebola virus challenge. Virology 2009, 383, 348-361. [CrossRef] [PubMed]

140. Bukreyev, A.; Yang, L.; Zaki, S.R.; Shieh, W.J.; Rollin, P.E.; Murphy, B.R.; Collins, P.L.; Sanchez, A. A single intranasal inoculation with a paramyxovirus-vectored vaccine protects guinea pigs against a lethal-dose Ebola virus challenge. J. Virol. 2006, 80, 2267-2279. [CrossRef] [PubMed]

141. Marzi, A.; Murphy, A.A.; Feldmann, F.; Parkins, C.J.; Haddock, E.; Hanley, P.W.; Emery, M.J.; Engelmann, F.; Messaoudi, I.; Feldmann, H.; et al. Cytomegalovirus-based vaccine expressing Ebola virus glycoprotein protects nonhuman primates from Ebola virus infection. Sci. Rep. 2016, 6, 21674. [CrossRef]

142. Blaney, J.E.; Marzi, A.; Willet, M.; Papaneri, A.B.; Wirblich, C.; Feldmann, F.; Holbrook, M.; Jahrling, P.; Feldmann, H.; Schnell, M.J. Antibody quality and protection from lethal Ebola virus challenge in nonhuman primates immunized with rabies virus based bivalent vaccine. PLoS Pathog. 2013, 9, e1003389. [CrossRef]

143. Willet, M.; Kurup, D.; Papaneri, A.; Wirblich, C.; Hooper, J.W.; Kwilas, S.A.; Keshwara, R.; Hudacek, A.; Beilfuss, S.; Rudolph, G.; et al. Preclinical Development of Inactivated Rabies Virus-Based Polyvalent Vaccine against Rabies and Filoviruses. J. Infect. Dis. 2015, 212 (Suppl. 2), S414-S424. [CrossRef]

144. Domi, A.; Feldmann, F.; Basu, R.; McCurley, N.; Shifflett, K.; Emanuel, J.; Hellerstein, M.S.; Guirakhoo, F.; Orlandi, C.; Flinko, R.; et al. A Single Dose of Modified Vaccinia Ankara expressing Ebola Virus Like Particles Protects Nonhuman Primates from Lethal Ebola Virus Challenge. Sci. Rep. 2018, 8, 864. [CrossRef]

145. Jones, S.M.; Feldmann, H.; Ströher, U.; Geisbert, J.B.; Fernando, L.; Grolla, A.; Klenk, H.D.; Sullivan, N.J.; Volchkov, V.E.; Fritz, E.A.; et al. Live attenuated recombinant vaccine protects nonhuman primates against Ebola and Marburg viruses. Nat. Med. 2005, 11, 786-790. [CrossRef]

146. Matassov, D.; Marzi, A.; Latham, T.; Xu, R.; Ota-Setlik, A.; Feldmann, F.; Geisbert, J.B.; Mire, C.E.; Hamm, S.; Nowak, B.; et al. Vaccination with a Highly Attenuated Recombinant Vesicular Stomatitis Virus Vector Protects against Challenge with a Lethal Dose of Ebola Virus. J. Infect. Dis. 2015, 212 (Suppl. 2), S443-S451. [CrossRef]

147. ClinicalTrials. Available online: https://clinicaltrials.gov/ct2/show/NCT02464670 (accessed on 4 May 2020).

148. ClinicalTrials. Available online: https://clinicaltrials.gov/ct2/show/NCT04041570 (accessed on 5 May 2020).

149. Wang, Y.; Li, J.; Hu, Y.; Liang, Q.; Wei, M.; Zhu, F. Ebola vaccines in clinical trial: The promising candidates. Hum. Vaccines Immunother. 2017, 13, 153-168. [CrossRef] [PubMed]

150. ClinicalTrials. Available online: https://clinicaltrials.gov/ct2/show/NCT00072605 (accessed on 6 May 2020). 
151. Meyer, M.; Garron, T.; Lubaki, N.M.; Mire, C.E.; Fenton, K.A.; Klages, C.; Olinger, G.G.; Geisbert, T.W.; Collins, P.L.; Bukreyev, A. Aerosolized Ebola vaccine protects primates and elicits lung-resident $\mathrm{T}$ cell responses. J. Clin. Investig. 2015, 125, 3241-3255. [CrossRef] [PubMed]

152. ClinicalTrials. Available online: https://clinicaltrials.gov/ct2/show/NCT03462004 (accessed on 11 May 2020).

153. ClinicalTrials. Available online: https://clinicaltrials.gov/ct2/show/NCT02495246 (accessed on 12 May 2020).

154. Ewer, K.; Rampling, T.; Venkatraman, N.; Bowyer, G.; Wright, D.; Lambe, T.; Imoukhuede, E.B.; Payne, R.; Fehling, S.K.; Strecker, T.; et al. A Monovalent Chimpanzee Adenovirus Ebola Vaccine Boosted with MVA. N. Engl. J. Med. 2015, 374, 1635-1646. [CrossRef]

155. Zhu, F.C.; Wurie, A.H.; Hou, L.H.; Liang, Q.; Li, Y.H.; Russell, J.B.; Wu, S.P.; Li, J.X.; Hu, Y.M.; Guo, Q.; et al. Safety and immunogenicity of a recombinant adenovirus type-5 vector-based Ebola vaccine in healthy adults in Sierra Leone: A single-centre, randomised, double-blind, placebo-controlled, phase 2 trial. Lancet (Lond. Engl.) 2017, 389, 621-628. [CrossRef]

156. De Santis, O.; Audran, R.; Pothin, E.; Warpelin-Decrausaz, L.; Vallotton, L.; Wuerzner, G.; Cochet, C.; Estoppey, D.; Steiner-Monard, V.; Lonchampt, S.; et al. Safety and immunogenicity of a chimpanzee adenovirus-vectored Ebola vaccine in healthy adults: A randomised, double-blind, placebo-controlled, dose-finding, phase 1/2a study. Lancet Infect. Dis. 2016, 16, 311-320. [CrossRef]

157. ClinicalTrials. Available online: https://clinicaltrials.gov/ct2/show/NCT02548078 (accessed on 14 May 2020).

158. ClinicalTrials. Available online: https://clinicaltrials.gov/ct2/show/NCT02876328 (accessed on 15 May 2020).

159. ClinicalTrials. Available online: https://clinicaltrials.gov/ct2/show/NCT02344407 (accessed on 21 May 2020).

160. ClinicalTrials. Available online: https://clinicaltrials.gov/ct2/show/NCT04152486 (accessed on 12 August 2020).

161. ClinicalTrials. Available online: https://linicaltrials.gov/ct2/show/NCT03072030 (accessed on 8 May 2020).

162. Dolzhikova, I.V.; Zubkova, O.V.; Tukhvatulin, A.I.; Dzharullaeva, A.S.; Tukhvatulina, N.M.; Shcheblyakov, D.V.; Shmarov, M.M.; Tokarskaya, E.A.; Simakova, Y.V.; Egorova, D.A.; et al. Safety and immunogenicity of GamEvac-Combi, a heterologous VSV- and Ad5-vectored Ebola vaccine: An open phase I/II trial in healthy adults in Russia. Hum. Vaccines Immunother. 2017, 13, 613-620. [CrossRef]

163. Rose, N.F.; Marx, P.A.; Luckay, A.; Nixon, D.F.; Moretto, W.J.; Donahoe, S.M.; Montefiori, D.; Roberts, A.; Buonocore, L.; Rose, J.K. An effective AIDS vaccine based on live attenuated vesicular stomatitis virus recombinants. Cell 2001, 106, 539-549. [CrossRef]

164. Agnandji, S.T.; Huttner, A.; Zinser, M.E.; Njuguna, P.; Dahlke, C.; Fernandes, J.F.; Yerly, S.; Dayer, J.-A.; Kraehling, V.; Kasonta, R. Phase 1 trials of rVSV Ebola vaccine in Africa and Europe. N. Engl. J. Med. 2016, 374, 1647-1660. [CrossRef]

165. Huttner, A.; Dayer, J.A.; Yerly, S.; Combescure, C.; Auderset, F.; Desmeules, J.; Eickmann, M.; Finckh, A.; Goncalves, A.R.; Hooper, J.W.; et al. The effect of dose on the safety and immunogenicity of the VSV Ebola candidate vaccine: A randomised double-blind, placebo-controlled phase $1 / 2$ trial. Lancet Infect. Dis. 2015, 15, 1156-1166. [CrossRef]

166. Wagner, R.R. Rhabdoviridae: The Viruses and Their Replication; Lippincott-Raven: Philadelphia, PA, USA, 1996; pp. 1121-1136.

167. Marzi, A.; Robertson, S.J.; Haddock, E.; Feldmann, F.; Hanley, P.W.; Scott, D.P.; Strong, J.E.; Kobinger, G.; Best, S.M.; Feldmann, H. EBOLA VACCINE. VSV-EBOV rapidly protects macaques against infection with the 2014/15 Ebola virus outbreak strain. Science 2015, 349, 739-742. [CrossRef]

168. Ollmann Saphire, E. A Vaccine against Ebola Virus. Cell 2020, 181, 6. [CrossRef]

169. ERVEBO. Available online: https://www.fda.gov/vaccines-blood-biologics/ervebo (accessed on 14 July 2020).

170. Farooq, F.; Beck, K.; Paolino, K.M.; Phillips, R.; Waters, N.C.; Regules, J.A.; Bergmann-Leitner, E.S. Circulating follicular T helper cells and cytokine profile in humans following vaccination with the rVSV-ZEBOV Ebola vaccine. Sci. Rep. 2016, 6, 27944. [CrossRef]

171. Anywaine, Z.; Whitworth, H.; Kaleebu, P.; Praygod, G.; Shukarev, G.; Manno, D.; Kapiga, S.; Grosskurth, H.; Kalluvya, S.; Bockstal, V.; et al. Safety and Immunogenicity of a 2-Dose Heterologous Vaccination Regimen with Ad26.ZEBOV and MVA-BN-Filo Ebola Vaccines: 12-Month Data from a Phase 1 Randomized Clinical Trial in Uganda and Tanzania. J. Infect. Dis. 2019, 220, 46-56. [CrossRef]

172. Halfmann, P.; Kim, J.H.; Ebihara, H.; Noda, T.; Neumann, G.; Feldmann, H.; Kawaoka, Y. Generation of biologically contained Ebola viruses. Proc. Natl. Acad. Sci. USA 2008, 105, 1129-1133. [CrossRef]

173. Halfmann, P.; Ebihara, H.; Marzi, A.; Hatta, Y.; Watanabe, S.; Suresh, M.; Neumann, G.; Feldmann, H.; Kawaoka, Y. Replication-deficient ebolavirus as a vaccine candidate. J. Virol. 2009, 83, 3810-3815. [CrossRef] 
174. Rabies in Africa: From Its Origins to the Current Fight. Available online: https://www.pasteur.fr/en/rabiesafrica-its-origins-current-fight (accessed on 27 August 2020).

175. Johnson, R.F.; Kurup, D.; Hagen, K.R.; Fisher, C.; Keshwara, R.; Papaneri, A.; Perry, D.L.; Cooper, K.; Jahrling, P.B.; Wang, J.T.; et al. An Inactivated Rabies Virus-Based Ebola Vaccine, FILORAB1, Adjuvanted with Glucopyranosyl Lipid A in Stable Emulsion Confers Complete Protection in Nonhuman Primate Challenge Models. J. Infect. Dis. 2016, 214, S342-S354. [CrossRef] [PubMed]

176. Skwarczynski, M.; Toth, I. Peptide-based synthetic vaccines. Chem. Sci. 2016, 7, 842-854. [CrossRef]

177. Wu, S.; Yu, T.; Song, X.; Yi, S.; Hou, L.; Chen, W. Prediction and identification of mouse cytotoxic T lymphocyte epitopes in Ebola virus glycoproteins. Virol. J. 2012, 9, 111. [CrossRef]

178. Dikhit, M.R.; Kumar, S.; Vijaymahantesh; Sahoo, B.R.; Mansuri, R.; Amit, A.; Yousuf Ansari, M.; Sahoo, G.C.; Bimal, S.; Das, P. Computational elucidation of potential antigenic CTL epitopes in Ebola virus. Infect. Genet. Evol. J. Mol. Epidemiol. Evol. Genet. Infect. Dis. 2015, 36, 369-375. [CrossRef]

179. Khan, M.A.; Hossain, M.U.; Rakib-Uz-Zaman, S.M.; Morshed, M.N. Epitope-based peptide vaccine design and target site depiction against Ebola viruses: An immunoinformatics study. Scand. J. Immunol. 2015, 82, 25-34. [CrossRef] [PubMed]

180. Jain, S.; Baranwal, M. Computational analysis in designing T cell epitopes enriched peptides of Ebola glycoprotein exhibiting strong binding interaction with HLA molecules. J. Theor. Biol. 2019, 465, 34-44. [CrossRef] [PubMed]

181. Jain, S.; Baranwal, M. Conserved peptide vaccine candidates containing multiple Ebola nucleoprotein epitopes display interactions with diverse HLA molecules. Med Microbiol. Immunol. 2019, 208, 227-238. [CrossRef]

182. Feldmann, H.; Feldmann, F.; Marzi, A. Ebola: Lessons on Vaccine Development. Annu. Rev. Microbiol. 2018, 72, 423-446. [CrossRef]

183. Sridhar, S. Clinical development of Ebola vaccines. Ther. Adv. Vaccines 2015, 3, 125-138. [CrossRef]

184. Grant-Klein, R.J.; Altamura, L.A.; Schmaljohn, C.S. Progress in recombinant DNA-derived vaccines for Lassa virus and filoviruses. Virus Res. 2011, 162, 148-161. [CrossRef] [PubMed]

185. Croyle, M.A.; Patel, A.; Tran, K.N.; Gray, M.; Zhang, Y.; Strong, J.E.; Feldmann, H.; Kobinger, G.P. Nasal delivery of an adenovirus-based vaccine bypasses pre-existing immunity to the vaccine carrier and improves the immune response in mice. PLoS ONE 2008, 3, e3548. [CrossRef]

186. Jerebtsova, M.; Nekhai, S. Therapeutics for postexposure treatment of Ebola virus infection. Future Virol. 2015, 10, 221-232. [CrossRef] [PubMed]

187. Schneider-Futschik, E.K.; Hoyer, D.; Khromykh, A.A.; Baell, J.B.; Marsh, G.A.; Baker, M.A.; Li, J.; Velkov, T. Contemporary Anti-Ebola Drug Discovery Approaches and Platforms. ACS Infect. Dis. 2019, 5, 35-48. [CrossRef] [PubMed]

188. Geisbert, T.W.; Hensley, L.E.; Jahrling, P.B.; Larsen, T.; Geisbert, J.B.; Paragas, J.; Young, H.A.; Fredeking, T.M.; Rote, W.E.; Vlasuk, G.P. Treatment of Ebola virus infection with a recombinant inhibitor of factor VIIa/tissue factor: A study in rhesus monkeys. Lancet (Lond. Engl.) 2003, 362, 1953-1958. [CrossRef]

189. ARCA biopharma Receives FDA Orphan Drug Designation for rNAPc2 as a Potential Treatment for Ebola. Available online: https://www.businesswire.com/news/home/20141210005243/en/ARCA-biopharmaReceives-FDA-Orphan-Drug-Designation (accessed on 16 July 2020).

190. Wong, G.; Qiu, X.; Olinger, G.G.; Kobinger, G.P. Post-exposure therapy of filovirus infections. Trends Microbiol. 2014, 22, 456-463. [CrossRef]

191. Geisbert, T.W.; Lee, A.C.; Robbins, M.; Geisbert, J.B.; Honko, A.N.; Sood, V.; Johnson, J.C.; de Jong, S.; Tavakoli, I.; Judge, A.; et al. Postexposure protection of non-human primates against a lethal Ebola virus challenge with RNA interference: A proof-of-concept study. Lancet (Lond. Engl.) 2010, 375, 1896-1905. [CrossRef]

192. Geisbert, T.W. Emergency Treatment for Exposure to Ebola Virus: The Need to Fast-track Promising Vaccines. JAMA 2015, 313, 1221-1222. [CrossRef] [PubMed]

193. Dunning, J.; Sahr, F.; Rojek, A.; Gannon, F.; Carson, G.; Idriss, B.; Massaquoi, T.; Gandi, R.; Joseph, S.; Osman, H.K.; et al. Experimental Treatment of Ebola Virus Disease with TKM-130803: A Single-Arm Phase 2 Clinical Trial. PLoS Med. 2016, 13, e1001997. [CrossRef] [PubMed] 
194. Warren, T.K.; Warfield, K.L.; Wells, J.; Swenson, D.L.; Donner, K.S.; Van Tongeren, S.A.; Garza, N.L.; Dong, L.; Mourich, D.V.; Crumley, S.; et al. Advanced antisense therapies for postexposure protection against lethal filovirus infections. Nat. Med. 2010, 16, 991-994. [CrossRef]

195. Heald, A.E.; Iversen, P.L.; Saoud, J.B.; Sazani, P.; Charleston, J.S.; Axtelle, T.; Wong, M.; Smith, W.B.; Vutikullird, A.; Kaye, E. Safety and pharmacokinetic profiles of phosphorodiamidate morpholino oligomers with activity against ebola virus and marburg virus: Results of two single-ascending-dose studies. Antimicrob. Agents Chemother. 2014, 58, 6639-6647. [CrossRef]

196. Martinez, M.J.; Salim, A.M.; Hurtado, J.C.; Kilgore, P.E. Ebola Virus Infection: Overview and Update on Prevention and Treatment. Infect. Dis. Ther. 2015, 4, 365-390. [CrossRef]

197. Warren, T.K.; Wells, J.; Panchal, R.G.; Stuthman, K.S.; Garza, N.L.; Van Tongeren, S.A.; Dong, L.; Retterer, C.J.; Eaton, B.P.; Pegoraro, G.; et al. Protection against filovirus diseases by a novel broad-spectrum nucleoside analogue BCX4430. Nature 2014, 508, 402-405. [CrossRef] [PubMed]

198. Furuta, Y.; Komeno, T.; Nakamura, T. Favipiravir (T-705), a broad spectrum inhibitor of viral RNA polymerase. Proc. Jpn. Academy. Ser. B Phys. Biol. Sci. 2017, 93, 449-463. [CrossRef]

199. Smither, S.J.; Eastaugh, L.S.; Steward, J.A.; Nelson, M.; Lenk, R.P.; Lever, M.S. Post-exposure efficacy of oral T-705 (Favipiravir) against inhalational Ebola virus infection in a mouse model. Antivir. Res. 2014, 104, 153-155. [CrossRef]

200. Bixler, S.L.; Bocan, T.M.; Wells, J.; Wetzel, K.S.; Van Tongeren, S.A.; Dong, L.; Garza, N.L.; Donnelly, G.; Cazares, L.H.; Nuss, J.; et al. Efficacy of favipiravir (T-705) in nonhuman primates infected with Ebola virus or Marburg virus. Antivir. Res. 2018, 151, 97-104. [CrossRef] [PubMed]

201. Mentré, F.; Taburet, A.M.; Guedj, J.; Anglaret, X.; Keïta, S.; de Lamballerie, X.; Malvy, D. Dose regimen of favipiravir for Ebola virus disease. Lancet Infect. Dis. 2015, 15, 150-151. [CrossRef]

202. Warren, T.K.; Jordan, R.; Lo, M.K.; Ray, A.S.; Mackman, R.L.; Soloveva, V.; Siegel, D.; Perron, M.; Bannister, R.; Hui, H.C.; et al. Therapeutic efficacy of the small molecule GS-5734 against Ebola virus in rhesus monkeys. Nature 2016, 531, 381-385. [CrossRef]

203. Ebola Treatments Approved for Compassionate Use in Current Outbreak. Available online: https://www. who.int/ebola/drc-2018/treatments-approved-for-compassionate-use/en/ (accessed on 16 July 2020).

204. Edwards, M.R.; Basler, C.F. Current status of small molecule drug development for Ebola virus and other filoviruses. Curr. Opin. Virol. 2019, 35, 42-56. [CrossRef] [PubMed]

205. Pardo, J.; Shukla, A.M.; Chamarthi, G.; Gupte, A. The journey of remdesivir: From Ebola to COVID-19. Drugs Context 2020, 9. [CrossRef]

206. Basu, A.; Li, B.; Mills, D.M.; Panchal, R.G.; Cardinale, S.C.; Butler, M.M.; Peet, N.P.; Majgier-Baranowska, H.; Williams, J.D.; Patel, I.; et al. Identification of a small-molecule entry inhibitor for filoviruses. J. Virol. 2011, 85, 3106-3119. [CrossRef]

207. Panchal, R.G.; Reid, S.P.; Tran, J.P.; Bergeron, A.A.; Wells, J.; Kota, K.P.; Aman, J.; Bavari, S. Identification of an antioxidant small-molecule with broad-spectrum antiviral activity. Antivir. Res. 2012, 93, 23-29. [CrossRef] [PubMed]

208. Wolf, M.C.; Freiberg, A.N.; Zhang, T.; Akyol-Ataman, Z.; Grock, A.; Hong, P.W.; Li, J.; Watson, N.F.; Fang, A.Q.; Aguilar, H.C.; et al. A broad-spectrum antiviral targeting entry of enveloped viruses. Proc. Natl. Acad. Sci. USA 2010, 107, 3157-3162. [CrossRef] [PubMed]

209. Aman, M.J.; Kinch, M.S.; Warfield, K.; Warren, T.; Yunus, A.; Enterlein, S.; Stavale, E.; Wang, P.; Chang, S.; Tang, Q.; et al. Development of a broad-spectrum antiviral with activity against Ebola virus. Antivir. Res. 2009, 83, 245-251. [CrossRef]

210. Warren, T.K.; Warfield, K.L.; Wells, J.; Enterlein, S.; Smith, M.; Ruthel, G.; Yunus, A.S.; Kinch, M.S.; Goldblatt, M.; Aman, M.J.; et al. Antiviral activity of a small-molecule inhibitor of filovirus infection. Antimicrob. Agents Chemother. 2010, 54, 2152-2159. [CrossRef]

211. Kinch, M.S.; Yunus, A.S.; Lear, C.; Mao, H.; Chen, H.; Fesseha, Z.; Luo, G.; Nelson, E.A.; Li, L.; Huang, Z.; et al. FGI-104: A broad-spectrum small molecule inhibitor of viral infection. Am. J. Transl. Res. 2009, 1, 87-98. [CrossRef]

212. Bray, M.; Driscoll, J.; Huggins, J.W. Treatment of lethal Ebola virus infection in mice with a single dose of an S-adenosyl-L-homocysteine hydrolase inhibitor. Antivir. Res. 2000, 45, 135-147. [CrossRef] 
213. Johansen, L.M.; Brannan, J.M.; Delos, S.E.; Shoemaker, C.J.; Stossel, A.; Lear, C.; Hoffstrom, B.G.; Dewald, L.E.; Schornberg, K.L.; Scully, C.; et al. FDA-approved selective estrogen receptor modulators inhibit Ebola virus infection. Sci. Transl. Med. 2013, 5, 190ra179. [CrossRef] [PubMed]

214. Balzarini, J. Targeting the glycans of glycoproteins: A novel paradigm for antiviral therapy. Nat. Rev. Microbiol. 2007, 5, 583-597. [CrossRef] [PubMed]

215. Lee, C. Griffithsin, a Highly Potent Broad-Spectrum Antiviral Lectin from Red Algae: From Discovery to Clinical Application. Mar. Drugs 2019, 17, 567. [CrossRef] [PubMed]

216. Michelow, I.C.; Lear, C.; Scully, C.; Prugar, L.I.; Longley, C.B.; Yantosca, L.M.; Ji, X.; Karpel, M.; Brudner, M.; Takahashi, K.; et al. High-dose mannose-binding lectin therapy for Ebola virus infection. J. Infect. Dis. 2011, 203, 175-179. [CrossRef] [PubMed]

217. ClinicalTrials. Available online: https://clinicaltrials.gov/ct2/show/NCT0231977279 (accessed on 3 October 2020).

218. Sissoko, D.; Laouenan, C.; Folkesson, E.; M’Lebing, A.B.; Beavogui, A.H.; Baize, S.; Camara, A.M.; Maes, P.; Shepherd, S.; Danel, C.; et al. Correction: Experimental Treatment with Favipiravir for Ebola Virus Disease (the JIKI Trial): A Historically Controlled, Single-Arm Proof-of-Concept Trial in Guinea. PLoS Med. 2016, 13, e1002009. [CrossRef] [PubMed]

219. Binning, J.M.; Wang, T.; Luthra, P.; Shabman, R.S.; Borek, D.M.; Liu, G.; Xu, W.; Leung, D.W.; Basler, C.F.; Amarasinghe, G.K. Development of RNA aptamers targeting Ebola virus VP35. Biochemistry 2013, 52, 8406-8419. [CrossRef]

220. ClinicalTrials. Available online: https://clinicaltrials.gov/ct2/show/NCT01353027 (accessed on 4 October 2020).

221. ClinicalTrials. Available online: https://clinicaltrials.gov/ct2/show/NCT02041715 (accessed on 2 October 2020).

222. Han, Z.; Lu, J.; Liu, Y.; Davis, B.; Lee, M.S.; Olson, M.A.; Ruthel, G.; Freedman, B.D.; Schnell, M.J.; Wrobel, J.E.; et al. Small-molecule probes targeting the viral PPxY-host Nedd4 interface block egress of a broad range of RNA viruses. J. Virol. 2014, 88, 7294-7306. [CrossRef] [PubMed]

223. ClinicalTrials. Available online: https://clinicaltrials.gov/ct2/show/NCT02818582 (accessed on 1 October 2020).

224. Gaudinski, M.R.; Coates, E.E.; Novik, L.; Widge, A.; Houser, K.V.; Burch, E.; Holman, L.A.; Gordon, I.J.; Chen, G.L.; Carter, C.; et al. Safety, tolerability, pharmacokinetics, and immunogenicity of the therapeutic monoclonal antibody mAb114 targeting Ebola virus glycoprotein (VRC 608): An open-label phase 1 study. Lancet (Lond. Engl.) 2019, 393, 889-898. [CrossRef]

225. Pettitt, J.; Zeitlin, L.; Kim, D.H.; Working, C.; Johnson, J.C.; Bohorov, O.; Bratcher, B.; Hiatt, E.; Hume, S.D.; Johnson, A.K.; et al. Therapeutic intervention of Ebola virus infection in rhesus macaques with the MB-003 monoclonal antibody cocktail. Sci. Transl. Med. 2013, 5, 199ra113. [CrossRef] [PubMed]

226. Qiu, X.; Audet, J.; Wong, G.; Pillet, S.; Bello, A.; Cabral, T.; Strong, J.E.; Plummer, F.; Corbett, C.R.; Alimonti, J.B.; et al. Successful treatment of ebola virus-infected cynomolgus macaques with monoclonal antibodies. Sci. Transl. Med. 2012, 4, 138ra181. [CrossRef]

227. Qiu, X.; Wong, G.; Audet, J.; Bello, A.; Fernando, L.; Alimonti, J.B.; Fausther-Bovendo, H.; Wei, H.; Aviles, J.; Hiatt, E.; et al. Reversion of advanced Ebola virus disease in nonhuman primates with ZMapp. Nature 2014, 514, 47-53. [CrossRef] [PubMed]

228. Qiu, X.; Audet, J.; Lv, M.; He, S.; Wong, G.; Wei, H.; Luo, L.; Fernando, L.; Kroeker, A.; Fausther Bovendo, H.; et al. Two-mAb cocktail protects macaques against the Makona variant of Ebola virus. Sci. Transl. Med. 2016, 8, 329ra333. [CrossRef] [PubMed]

229. Keller, M.A.; Stiehm, E.R. Passive immunity in prevention and treatment of infectious diseases. Clin. Microbiol. Rev. 2000, 13, 602-614. [CrossRef]

230. van Griensven, J.; De Weiggheleire, A.; Delamou, A.; Smith, P.G.; Edwards, T.; Vandekerckhove, P.; Bah, E.I.; Colebunders, R.; Herve, I.; Lazaygues, C.; et al. The Use of Ebola Convalescent Plasma to Treat Ebola Virus Disease in Resource-Constrained Settings: A Perspective from the Field. Clin. Infect. Dis. Off. Publ. Infect. Dis. Soc. Am. 2016, 62, 69-74. [CrossRef]

231. Mupapa, K.; Massamba, M.; Kibadi, K.; Kuvula, K.; Bwaka, A.; Kipasa, M.; Colebunders, R.; Muyembe-Tamfum, J.J. Treatment of Ebola hemorrhagic fever with blood transfusions from convalescent patients. International Scientific and Technical Committee. J. Infect. Dis. 1999, 179 (Suppl. 1), S18-S23. [CrossRef] [PubMed]

232. Mendoza, E.J.; Racine, T.; Kobinger, G.P. The ongoing evolution of antibody-based treatments for Ebola virus infection. Immunotherapy 2017, 9, 435-450. [CrossRef] [PubMed] 
233. Mora-Rillo, M.; Arsuaga, M.; Ramírez-Olivencia, G.; de la Calle, F.; Borobia, A.M.; Sánchez-Seco, P.; Lago, M.; Figueira, J.C.; Fernández-Puntero, B.; Viejo, A.; et al. Acute respiratory distress syndrome after convalescent plasma use: Treatment of a patient with Ebola virus disease contracted in Madrid, Spain. Lancet Respir. Med. 2015, 3, 554-562. [CrossRef]

234. Moekotte, A.L.; Huson, M.A.; van der Ende, A.J.; Agnandji, S.T.; Huizenga, E.; Goorhuis, A.; Grobusch, M.P. Monoclonal antibodies for the treatment of Ebola virus disease. Expert Opin. Investig. Drugs 2016, 25, 1325-1335. [CrossRef]

235. Oswald, W.B.; Geisbert, T.W.; Davis, K.J.; Geisbert, J.B.; Sullivan, N.J.; Jahrling, P.B.; Parren, P.W.; Burton, D.R. Neutralizing antibody fails to impact the course of Ebola virus infection in monkeys. PLoS Pathog. 2007, 3, e9. [CrossRef]

236. Corti, D.; Misasi, J.; Mulangu, S.; Stanley, D.A.; Kanekiyo, M.; Wollen, S.; Ploquin, A.; Doria-Rose, N.A.; Staupe, R.P.; Bailey, M.; et al. Protective monotherapy against lethal Ebola virus infection by a potently neutralizing antibody. Science 2016, 351, 1339-1342. [CrossRef]

237. Wilson, J.A.; Hevey, M.; Bakken, R.; Guest, S.; Bray, M.; Schmaljohn, A.L.; Hart, M.K. Epitopes involved in antibody-mediated protection from Ebola virus. Science 2000, 287, 1664-1666. [CrossRef] [PubMed]

238. Olinger, G.G., Jr.; Pettitt, J.; Kim, D.; Working, C.; Bohorov, O.; Bratcher, B.; Hiatt, E.; Hume, S.D.; Johnson, A.K.; Morton, J.; et al. Delayed treatment of Ebola virus infection with plant-derived monoclonal antibodies provides protection in rhesus macaques. Proc. Natl. Acad. Sci. USA 2012, 109, 18030-18035. [CrossRef] [PubMed]

239. Qiu, X.; Fernando, L.; Melito, P.L.; Audet, J.; Feldmann, H.; Kobinger, G.; Alimonti, J.B.; Jones, S.M. Ebola GP-specific monoclonal antibodies protect mice and guinea pigs from lethal Ebola virus infection. PLoS Negl. Trop. Dis. 2012, 6, e1575. [CrossRef]

240. Qiu, X.; Audet, J.; Wong, G.; Fernando, L.; Bello, A.; Pillet, S.; Alimonti, J.B.; Kobinger, G.P. Sustained protection against Ebola virus infection following treatment of infected nonhuman primates with ZMAb. Sci. Rep. 2013, 3, 3365. [CrossRef] [PubMed]

241. Qiu, X.; Wong, G.; Fernando, L.; Audet, J.; Bello, A.; Strong, J.; Alimonti, J.B.; Kobinger, G.P. mAbs and Ad-vectored IFN- $\alpha$ therapy rescue Ebola-infected nonhuman primates when administered after the detection of viremia and symptoms. Sci. Transl. Med. 2013, 5, 207ra143. [CrossRef] [PubMed]

242. Zeitlin, L.; Whaley, K.J.; Olinger, G.G.; Jacobs, M.; Gopal, R.; Qiu, X.; Kobinger, G.P. Antibody therapeutics for Ebola virus disease. Curr. Opin. Virol. 2016, 17, 45-49. [CrossRef] [PubMed]

243. Lyon, G.M.; Mehta, A.K.; Varkey, J.B.; Brantly, K.; Plyler, L.; McElroy, A.K.; Kraft, C.S.; Towner, J.S.; Spiropoulou, C.; Ströher, U.; et al. Clinical care of two patients with Ebola virus disease in the United States. N. Engl. J. Med. 2014, 371, 2402-2409. [CrossRef]

244. Mendoza, E.J.; Qiu, X.; Kobinger, G.P. Progression of Ebola Therapeutics during the 2014-2015 Outbreak. Trends Mol. Med. 2016, 22, 164-173. [CrossRef] [PubMed]

245. Cowled, C.; Stewart, C.R.; Likic, V.A.; Friedländer, M.R.; Tachedjian, M.; Jenkins, K.A.; Tizard, M.L.; Cottee, P.; Marsh, G.A.; Zhou, P.; et al. Characterisation of novel microRNAs in the Black flying fox (Pteropus alecto) by deep sequencing. BMC Genom. 2014, 15, 682. [CrossRef]

246. Sanjuan, M.A.; Dillon, C.P.; Tait, S.W.; Moshiach, S.; Dorsey, F.; Connell, S.; Komatsu, M.; Tanaka, K.; Cleveland, J.L.; Withoff, S.; et al. Toll-like receptor signalling in macrophages links the autophagy pathway to phagocytosis. Nature 2007, 450, 1253-1257. [CrossRef]

247. Shtanko, O.; Reyes, A.N.; Jackson, W.T.; Davey, R.A. Autophagy-Associated Proteins Control Ebola Virus Internalization into Host Cells. J. Infect. Dis. 2018, 218, S346-S354. [CrossRef] [PubMed]

248. Emond, R.T.; Evans, B.; Bowen, E.T.; Lloyd, G. A case of Ebola virus infection. Br. Med. J. 1977, 2, 541-544. [CrossRef] [PubMed]

249. Martinez, O.; Ndungo, E.; Tantral, L.; Miller, E.H.; Leung, L.W.; Chandran, K.; Basler, C.F. A mutation in the Ebola virus envelope glycoprotein restricts viral entry in a host species- and cell-type-specific manner. J. Virol. 2013, 87, 3324-3334. [CrossRef]

250. Bedoui, S.; Whitney, P.G.; Waithman, J.; Eidsmo, L.; Wakim, L.; Caminschi, I.; Allan, R.S.; Wojtasiak, M.; Shortman, K.; Carbone, F.R.; et al. Cross-presentation of viral and self antigens by skin-derived CD103+ dendritic cells. Nat. Immunol. 2009, 10, 488-495. [CrossRef] [PubMed]

251. Racine, T.; Kobinger, G.P. Viral pathogenesis: Unlocking Ebola persistence. Nat. Microbiol. 2017, $2,17124$. [CrossRef] 
252. Gutierrez, M.G.; Munafó, D.B.; Berón, W.; Colombo, M.I. Rab7 is required for the normal progression of the autophagic pathway in mammalian cells. J. Cell Sci. 2004, 117, 2687-2697. [CrossRef]

253. Wong, G.; Audet, J.; Fernando, L.; Fausther-Bovendo, H.; Alimonti, J.B.; Kobinger, G.P.; Qiu, X. Immunization with vesicular stomatitis virus vaccine expressing the Ebola glycoprotein provides sustained long-term protection in rodents. Vaccine 2014, 32, 5722-5729. [CrossRef] [PubMed]

254. Ndungo, E.; Herbert, A.S.; Raaben, M.; Obernosterer, G.; Biswas, R.; Miller, E.H.; Wirchnianski, A.S.; Carette, J.E.; Brummelkamp, T.R.; Whelan, S.P.; et al. A Single Residue in Ebola Virus Receptor NPC1 Influences Cellular Host Range in Reptiles. mSphere 2016, 1. [CrossRef]

Publisher's Note: MDPI stays neutral with regard to jurisdictional claims in published maps and institutional affiliations.

(C) 2020 by the authors. Licensee MDPI, Basel, Switzerland. This article is an open access article distributed under the terms and conditions of the Creative Commons Attribution (CC BY) license (http://creativecommons.org/licenses/by/4.0/). 